\title{
A "INVENÇÃO DO TRABALHO": historicidade de um conceito nas obras de André Gorz, Dominique Méda, Françoise Gollain e Serge Latouche ${ }^{1}$
}

\author{
Nuno Miguel Cardoso Machado*
}

\begin{abstract}
Após a publicação de Adeus ao Proletariado, em 1980, o entendimento do trabalho como uma atividade historicamente específica da modernidade capitalista é uma das traves-mestras do edifício teórico construído por André Gorz. O trabalho está intimamente associado ao surgimento de uma esfera econômica desvinculada da sociedade e, na qualidade de trabalho abstrato, ao fim, em si mesmo irracional, da valorização do valor. Neste artigo, pretendemos caracterizar detalhadamente a evolução do conceito de trabalho nas principais obras de Gorz e, depois, comparar a noção gorziana acerca da historicidade do trabalho com as ideias de três autores francófonos: Dominique Méda, Françoise Gollain e Serge Latouche. Procuraremos aferir as semelhanças e as divergências entre os autores mencionados. Finalmente, será salientado que as razões aventadas para o devir histórico do trabalho podem ser mais bem entendidas no contexto embrionário comum da "revolução militar", no século XVI, que inaugurou a era moderna no mundo ocidental.

Palavras-chave: Trabalho. Gorz. Méda. Gollain. Latouche.
\end{abstract}

\section{INTRODUÇÃO}

\begin{abstract}
A abordagem antropológica não permite [...] escamotear uma interrogação que, mais do que qualquer outra, pode ter fortes consequências teóricas e práticas: pode dizer-se que o trabalho existe quando ele não é pensado nem vivido como tal?"' (Chamoux, 2001, p. 69, grifo do autor).
\end{abstract}

André Gorz é, sem dúvida, um dos principais teóricos do trabalho da segunda metade do século XX (Castel, 2013; Granter, 2009, p. 113-134; Silva, 2002), sendo conhecido, sobretudo, pela sua obra tardia e, em particular, pelas suas teses polêmicas acerca da crise do capitalismo como sociedade do trabalho, na sequência da chamada $3^{\text {a }}$ Revolução Industrial (Gorz, 1982, 1985,1989a).

Todavia um dos aspetos fundamentais do pensamento gorziano sobre o trabalho tem passado virtualmente despercebido na litera-

* SOCIUS, ISEG, Universidade de Lisboa.

Rua Miguel Lupi, No 20, 1249-078 Lisboa, Portugal. nuno. cocas.machado@gmail.com

${ }^{1}$ Agradeço o apoio financeiro concedido pela Universidade de Lisboa no âmbito de uma Bolsa de Doutoramento. tura secundária, salvo raríssimas exceções: refiro-me à noção do trabalho como categoria moderna e, portanto, historicamente específica. O intuito deste artigo é colmatar essa lacuna através de uma análise detalhada dessa ideia, igualmente polêmica, adotada a partir de seus escritos da década de 1980. Segundo Gorz, o trabalho está intimamente associado ao surgimento de uma esfera econômica desvinculada da sociedade e, na qualidade de trabalho abstrato, ao fim, em si mesmo irracional, da valorização do valor.

Embora se trate de uma posição teórica minoritária, a noção de uma "invenção do trabalho", isto é, da sua emergência histórica, não é de modo algum incomum no mundo acadêmico francófono. ${ }^{2}$ Pode-se mesmo dizer que André Gorz desempenhou um importante papel pioneiro nesse âmbito, questionando o aparentemente inquestionável ${ }^{3}$ e abrindo caminho para

${ }^{2}$ Gorz (1989a) intitula justamente o capítulo 1 de Metamorfoses do Trabalho por "A invenção do trabalho". Os outros autores - Méda (2010), capítulo 3; Gollain, (2000), capítulo 8; Latouche (2005), capítulo 3 - que serão estudados neste ensaio utilizam igualmente esse termo nos títulos de vários capítulos de suas obras.

${ }^{3}$ A nocão ontológica e trans-histórica de trabalho é um dos postulados básicos de praticamente todas as teorias sociais modernas (Méda, 2010, p. 98-148). 
outros estudos críticos sobre o trabalho.

Assim, neste artigo, serão apresentadas também as reflexões de três autores franceses acerca da historicidade do trabalho que reconhecem a influência de Gorz em suas teorizações: Dominique Méda (2010, p. 139), Françoise Gollain (2000, p. 7) e Serge Latouche (2005, p. 231). No final, procederei a uma análise comparada com o intuito de discernir as principais convergências e divergências desses pensadores, que propõem uma (re)interpretação da história da humanidade que prima pela originalidade. Sugerirei, ainda, que as causas avançadas por esses autores para o surgimento histórico do trabalho podem ser mais bem apreendidas e fundamentadas no contexto da denominada "revolução militar" (Parker, 2013), no século XVI, que inaugurou a era moderna no mundo ocidental. ${ }^{4}$

\section{ANDRÉ GORZ E O TRABALHO}

Nesta seção será feita uma síntese da evolução do conceito de trabalho na obra de André Gorz. Ver-se-á que a década de 1980 representa uma rutura no pensamento do autor. A partir dessa altura o trabalho a a racionalidade económica passarão a ser entendidos como 옹 categorias especificamente capitalistas.

\section{O conceito de trabalho na obra gorziana das décadas de 1950, 1960 e 1970: breves apontamentos}

Durante a década de 1950, a filosofia existencialista de Jean-Paul Sartre foi a grande in influência de Gorz. Isso é patente em seus dois primeiros livros, Fondements pour une morale (1977) e The Traitor $^{6}$ (1989b), cujo conceito-

${ }^{4}$ Conforme será salientado mais à frente, o termo "revo- lução militar" refere-se à revolução das armas de fogo e à correspondente modificação na forma de conduzir a guerra ocorrida no século XVI, na Europa.

${ }^{5}$ Fundamentos para uma moral.

${ }^{6} \mathrm{O}$ traidor. -chave é o de alienação individual (Silva, 2002, p. 41). Gorz centra sua atenção na moralidade do indivíduo, nomeadamente na superação da "má-fé" sartreana e na busca de uma conduta ética "autêntica", defendendo que a autenticidade e a liberdade do sujeito encontram sua expressão plena na ação, na transformação prática do mundo (Gorz, 1977, p. 494-495). A liberdade é implicitamente equiparada aos predicados do homo faber.

A moral da história (1969), publicada originalmente em 1959, pode ser entendida como sua primeira obra marxista. O autor desloca o foco de sua análise para a alienação no plano social, isto é, para o trabalho alienado. $\mathrm{O}$ trabalho é definido explicitamente como uma categoria ontológica, constituindo a essência do ser humano. Ademais, é a manifestação par excellence da liberdade, da criatividade e da autonomia humanas que, porém, na sociedade capitalista, é desumanizada e mutilada. A superação da alienação passa pela libertação do domínio exterior que o capital exerce sobre o trabalhador. A missão do proletariado, como demiurgo da história, é a instauração de um socialismo estatista através da luta de classes.

Posteriormente, André Gorz publicou três livros durante a década de 1960: Estratégia operária e neocapitalismo (1975a), O socialismo difícil (1968) e Reforma e revolução (1975c). Esse período ilustra um compromisso inabalável com a teoria do marxismo tradicional. ${ }^{7} \mathrm{~A}$ classe operária ainda é o sujeito revolucionário apriorístico, responsável pela implementação do socialismo. O trabalho continua a ser entendido como uma constante antropológica e de modo positivo: Gorz (1975a, p. 151) destaca

\footnotetext{
7 O termo "marxismo tradicional" é utilizado de acordo com o sentido cunhado por Moishe Postone (2003). Segundo Postone, o marxismo tradicional abarca todas as teorias de inspiração marxista que apreendem o capitalismo apenas com base na propriedade privada dos meios de produção, nas relações de exploração e no mercado. A dominação impessoal, "quasi-objetiva", que carateriza o capitalismo, corporizada em abstrações reais - mercadoria, valor, trabalho, dinheiro, etc. -, é escamoteada em benefício de uma noção trans-histórica de dominação direta. Para além disso, o trabalho é entendido de modo positivo. Assim, se Marx critica o trabalho, como substância do capital, o marxismo tradicional é uma crítica (equivocada) do capitalismo "do ponto de vista do trabalho".
} 
a "essência ativa e potencialmente criadora do trabalho". A autogestão do processo de trabalho pelos conselhos operários é o conceito-chave para entender a sua teoria marxista, na qual o controlo operário da produção industrial é a forma privilegiada de combater a alienação no trabalho e de subverter a hegemonia do capital.

No socialismo, o trabalho qualificado será a norma; a autonomia, a atratividade e o enriquecimento das atividades produtivas consubstanciar-se-ão num trabalho "polivalente" (Gorz, 1968, p. 62), politécnico, que abolirá a divisão do trabalho. A força de trabalho deixará de ser algo estranho e passará a ser vivida "como coisa própria" pelos trabalhadores (Gorz, 1975a, p. 231, grifo do autor). A distinção entre "tempo livre" e "tempo de trabalho" deve ser abolida em proveito do segundo: a instauração de uma "cultura proletária” fará do tempo livre "um prolongamento, uma saída, um campo de aplicação particular da atividade social principal: o trabalho."(Gorz, 1968, p. 137-138). ${ }^{8}$

O início da década de 1970 não trouxe mudança crucial alguma ao entendimento trans-histórico e positivo do trabalho. Em Crítica do capitalismo quotidiano (1976a, 1976b) e, sobretudo, em Divisão do trabalho e modo de produção capitalista (1976), o autor aprofunda a crítica da divisão do trabalho, que "é a fonte de todas as alienações” (Gorz, 1976d, p. 7). Nesse sentido, a transição para o socialismo requer que a divisão do trabalho seja abolida e que o trabalho seja "progressivamente enriquecido”, permitindo aos operários desenvolverem capacidades criativas cada vez mais alargadas (Gorz, 1976e, p. 260).

A ciência aplicada e as técnicas de produção devem ser transformadas de modo a permitir acabar com a cisão entre trabalho manual e intelectual (Gorz, 1976d, p. 11). E a "emancipação da classe operária” passa, pois, pela reconquista de sua "integridade física, nervosa, intelectual, cultural, no seio do trabaIho, isto é, pela luta para impor um poder de

${ }^{8}$ Cf. Machado (2016c) para um estudo aprofundado do pensamento gorziano da década de 1960. autodeterminação do processo de trabalho.” (Gorz, 1976d, p. 11, grifo nosso).

Em suma, para o Gorz marxista tradicional, como seria de esperar, o trabalho é a eterna forma de mediação do intercâmbio material entre o homem e a natureza. O trabalho é o campo de desenvolvimento por excelência dos seres humanos e sua fonte primordial de identidade e de socialização. Porém, até aos dias de hoje, o trabalho nunca assumiu uma forma empírica adequada, devendo, pois, ser transformado de acordo com seu conceito, ou seja, tornar-se uma forma de atividade espontânea, autônoma, criativa. O trabalho real, alienado e capitalista, é contraposto ao trabalho ideal, não alienado, conforme à natureza do homo faber ou do animal laborans.

Esse quadro teórico começa a mudar com a descoberta de Ivan Illich (Machado, 2016a), que provoca um enorme impacto no pensamento de André Gorz. É legítimo falar-se de uma viragem ecológica inaugurada com Ecology as Politics ${ }^{9}$, publicada primeiramente em 1975, na qual a tecnologia é agora percebida como a matriz a priori que determina a forma das relações sociais capitalistas. Capitalismo e produção industrial são coextensivos, pelo que a apropriação coletiva dos meios de produção se torna impossível.

A produção industrial é, por definição, alienante, restando reduzir sua preponderância e estimular a produção autônoma microssocial - ecologicamente sustentável - com recurso às "ferramentas conviviais" illichianas. Embora o trabalho industrial ganhe progressivamente uma conotação negativa, Gorz ainda não o apreende claramente como uma atividade historicamente específica. ${ }^{10}$ Esse passo decisivo será dado somente em Adeus ao Proletariado, conforme veremos nos itens seguintes.
${ }^{9}$ Ecologia e Política.

${ }^{10}$ Cf. Machado (2016a) para um estudo detalhado da teoria gorziana da década de 1970. 


\section{Década de 1980: a grande transformação}

A década de 1980 e, em especial, a obra Farewell to the Working Class ${ }^{11}$ representa uma cisão no pensamento de André Gorz. Pode-se, com efeito, falar de um Gorz antes de Farewell to the Working Class e de um Gorz depois de Farewell to the Working Class, tal o grau de evolução e de transformação sofrido por sua teoria. ${ }^{12}$ Daqui em diante, seu pensamento será marcado por uma ruptura com a teoria marxista tradicional em três aspectos fundamentais:

1. Desnaturalização do trabalho, que passa a ser entendido como a forma de atividade produtiva hodierna, específica da sociedade capitalista;

2. O trabalho é, então, definido de um modo exclusivamente negativo, como atividade irremediavelmente "heterônoma" e "alienada”. Assim, o desafio que a Humanidade enfrenta não é libertar o trabalho, mas, antes, libertar-se do trabalho (uma possibilidade contida na $3^{\text {a }}$ Revolução Industrial - aquela da microeletrônica -, que permite um aumento sem precedentes da produtividade). $\mathrm{O}$ pleno desenvolvimento das capacidades humanas só é possível para além do trabalho, naquilo que Gorz denomina por "esfera da autonomia";

3. Crítica da noção de um "sujeito revolucionário" a priori - mormente, o proletariado - responsável pela emancipação da humanidade. Todavia, em Farewell to the Working Class, essa crítica permanece ambígua, pois Gorz deposita suas esperanças naquilo que designa por "não classe dos não trabalhadores": o grupo heterogêneo composto por indivíduos marginalizados (supérfluos), por desempregados, por trabalhadores precários, a tempo parcial, etc., que têm em comum a (suposta) rejeição dos valores capitalistas: trabalho, mercadorização das atividades humanas, ra-

${ }^{11}$ Adeus ao Proletariado.

${ }^{12}$ Cf. Machado (2016b) para uma análise da radicalização ulterior do pensamento de Gorz, no início da década de 2000, em virtude de sua descoberta da corrente de pensamento conhecida por Nova Crítica do Valor. cionalidade econômica. Ora, a "não classe" acaba ela própria por ser, paradoxalmente, um "sujeito objetivo". Essa aporia apenas será resolvida no final da década de 1980, em Metamorfoses do Trabalho.

Gorz publicou três obras durante a década de 1980. Farewell to the Working Class (1982) consiste, no essencial, numa crítica do marxismo tradicional, mormente do seu culto do trabalho e do papel revolucionário atribuído à classe operária. Paths to Paradise ${ }^{13}$ (Gorz, 1985), por seu turno, assume-se como uma obra sob a forma de teses, cuja ênfase recai sobre a análise objetiva da crise capitalista - em particular, do modelo fordista de crescimento econômico - e da sua relação íntima com a "revolução microeletrônica". Finalmente, $M e$ tamorfoses do Trabalho (Gorz, 1989a) é o culminar da ruptura teórica gorziana. Nessa obra, é exposto pela primeira vez, de um modo detalhado, o programa (utópico) de uma sociedade dual, composta por:

1. uma esfera heterônoma "macrossocial", insuperável, constituída pelo trabalho e pela racionalidade econômica;

2. uma esfera autônoma "microssocial", que comporta as atividades livremente escolhidas e realizadas pelos indivíduos.

O modelo de socialismo proposto por Gorz assenta na chamada "política do tempo": redução progressiva dos horários de trabalho heterônomo sem qualquer perda no salário real, mediante a atribuição de um "rendimento básico" a todos os cidadãos, que devem realizar um número mínimo de horas de trabalho ao longo de sua vida ativa.

\section{O Trabalho e a Racionalidade Econômica: categorias modernas}

Como foi mencionado no item anterior, um dos aspectos fulcrais da teoria gorziana da década de 1980 é a desnaturalização no trabalho. Ao contrário do que defende o marxismo ${ }^{13}$ Caminhos do Paraíso. 
tradicional, o trabalho não é a essência do ser humano. Segundo o autor,

O ‘trabalho’ tal como o conhecemos é uma invenção moderna. [...] Foi inventado, e subsequentemente generalizado, apenas com o advento do industrialismo. O 'trabalho', no sentido moderno, não tem qualquer relação com as tarefas, repetidas dia após dia, que são indispensáveis para a manutenção e reprodução das nossas vidas individuais. Nem deve ser confundido com a atividade árdua, não importa quão exigente ela seja (Gorz, 1989a, p. 13).

A sociedade industrial moderna é o berço do trabalho, de uma "[...] atividade puramente funcional, separada da vida, desligada da cultura, arrancada ao tecido da existência humana.” (Gorz, 1985, p. 49). O trabalho é indissociável da constituição de uma esfera econômica desvinculada, em termos temporais, espaciais e simbólicos, dos demais contextos da vida social. Trata-se de uma atividade abstrata, criadora de valor econômico, subsumida na reprodução do capital: na sociedade mercantil, “[...] o dinheiro [...] é o objetivo invariável de todas as atividades” (Gorz, 1985, p. 49).

Desse modo, o trabalho, no qual se baseia a coesão social e a cidadania das sociedades capitalistas, não pode ser elevado a categoria antropológica nem equiparado à necessidade de os seres humanos produzirem seus meios de subsistência. Para além disso, a atividade produtiva, isto é, o metabolismo com a natureza (Marx), "nunca foi um fator de integração social. Era, pelo contrário, um critério de exclusão: em todas as sociedades pré-modernas, aqueles que o efetuavam eram considerados inferiores. Eles eram escravos da necessidade" (Gorz, 1989a, p. 14) e, portanto, incapazes de cultivar o espírito elevado - que apenas a ociosidade permitia -, exigido pela gestão dos assuntos da cidade (Gorz, 1989a).

Seguindo de perto a teoria arendtiana (Arendt, 1998), Gorz preconiza que há uma diferença fulcral entre o "trabalho no capitalismo" e o "trabalho no mundo antigo": enquanto o primeiro é efetuado na esfera pública, o segundo estava confinado à "esfera privada" familiar. A esfera pública, lócus por excelência da política, constituía o verdadeiro reino da liberdade, do qual eram excluídas todas as atividades com caráter utilitário (Gorz, 1989a, p. 15). Ademais, nas sociedades pré-capitalistas, a produção material não era orientada pela "racionalidade econômica" (Gorz, 1989a, p. 16) subjacente à troca mercantil (Gorz, 1985, p. 49). As atividades produtivas estavam profundamente enraizadas em motivações não econômicas, ou seja, "não existia uma separação entre trabalho, cultura e vida"(Gorz, 1985, p. 49). A vida respeitava um padrão cíclico, governado por "ritmos sazonais e biológicos" e pontuado pelos múltiplos feriados associados a festividades e celebrações religiosas (Gorz, 1985, p. 49). As relações sociais e interpessoais obedeciam a princípios de reciprocidade, solidariedade e ajuda mútua (Gorz, 1985, p. 49).

A categoria moderna de trabalho surgiu apenas, então, com o advento do capitalismo industrial. A produção doméstica foi destronada pelo sistema manufatureiro e pelo triunfo do "espírito do capitalismo" (Gorz, 1989a, p. 18). Apoiando-se no individualismo metodológico de Max Weber, Gorz preconiza que foram as ações (e as motivações) individuais dos mercadores que engendraram o capitalismo, assim que o cálculo econômico conquistou a organização do processo de produção (Gorz, 1989a, p. 18). A racionalização promovida pelos primeiros capitalistas é explicada do seguinte modo:

A capacidade de calcular e prever os custos do trabalho com precisão era essencial para o seu negócio, visto que apenas desta forma era possível calcular o volume e o preço da mercadoria produzida, assim como o lucro esperado. Na ausência destas previsões, o risco envolvido na realização de investimentos seria demasiado elevado. Para tornar o custo do trabalho calculável, era necessário tornar o seu output igualmente calculável (Gorz, 1989a, p. 20).

Em síntese, a racionalização econômica é atribuída a essa necessidade de cálculo subjetivo dos custos de produção. A preocupação exclusiva com os "fatores financeiros" conduziu a "racionalidade econômica" a seu extre- 
mo. As relações predominantes entre os indivíduos tornaram-se aquelas de natureza monetária, enquanto a relação entre o ser humano e a natureza adquiriu um caráter puramente instrumental (Gorz, 1989a, p. 19).

Se a sociedade econômica emergente permitiu uma emancipação face às relações de dominação direta, ela erigiu, em seu lugar, uma ordem "imperiosa", regida por "leis objetivas inapeláveis", independentes de qualquer vontade humana (Gorz, 1989a, p. 112). Entrou em vigor a concorrência perpétua mediante a qual os indivíduos procuram ser bem-sucedidos à custa dos demais. A razão econômica elimina todos os critérios que permitiriam às pessoas ficarem satisfeitas com aquilo que possuem ou com aquilo que fazem (Gorz, 1989a, p. 113), sendo essa racionalização econômica das atividades produtivas que, na perspetiva de Gorz, cria o trabalho no sentido moderno do termo. Vejamos como.

No final do século XVIII, o "trabalho" ainda era parte integrante de um ritmo de vida tradicional, imutável e religiosamente respeitado. Para os indivíduos, era impensável "intensificar ou prolongar os seus esforços de modo a conseguirem ganhar mais [dinheiro, NM]” (Gorz, 1989a, p. 21). Essa relutância em realizar um dia de trabalho completo apenas ^ pôde ser ultrapassada pela burguesia nascente ثั. através da diminuição radical dos salários, de ¿ modo que fosse necessário trabalhar 14, 16 ou mais horas diárias para conseguir sobreviver. Os trabalhadores oriundos dos meios rurais e artesanais, em particular, possuíam hábitos de ociosidade e de relaxamento difíceis de quebrar, incompatíveis com a disciplina fabril (Gorz, 1989a, p. 21).

Nesse sentido,

A racionalização econômica do trabalho não consistiu, portanto, meramente em tornar atividades produtivas preexistentes mais metódicas e mais bem adaptadas ao seu objeto. Ela foi uma revolução, uma subversão do modo de vida, dos valores, das relações sociais e da relação com a Natureza, a invenção no verdadeiro sentido da palavra de algo que nunca tinha existido antes. A atividade produtiva foi desacoplada do seu significado, das suas motivações e do seu objeto e tornou-se simplesmente um meio de ganhar um salário. Deixou de ser uma parte da vida e tornou-se no meio de 'ganhar a vida'. O tempo de trabalho e o tempo de vida foram separados; o trabalho, as suas ferramentas e os seus produtos adquiriram uma realidade distinta daquela do trabalhador [...]. A satisfação de "produzir obras" em conjunto e o prazer derivado do "fazer" foram abolidos em favor daquelas satisfações que o dinheiro pode comprar. Por outras palavras, o trabalho concreto apenas pôde ser transformado naquilo que Marx chama de "trabalho abstrato" mediante a transformação do trabalhador/produtor em trabalhador/consumidor (Gorz, 1989a, p. 21-22, grifo do autor).

Como atividade econômica par excellence, o trabalho presta-se a ser tratado como uma "unidade material quantificável”, pois é possível medi-lo como uma "entidade independente"; os trabalhadores são despojados de sua individualidade, assumindo-se como simples portadores de "força de trabalho" abstrata e intercambiável (Gorz, 1989a, p. 20). A subjetividade é uniformizada, visto que os trabalhadores funcionam de maneira "quase automática" (Gorz, 1989a, p. 122-123), e as personalidades dos indivíduos tendem a ser destruídas pela "compulsão ao trabalho, de maneira que eles não conhecem nada para além do desejo de mais trabalho" (Gorz, 1989a, p. 117).

Enquanto as sociedades pré-capitalistas repousavam sobre as certezas eternas asseguradas pelas normas religiosas e morais, nas sociedades capitalistas é a racionalidade econômica que cumpre essa função apaziguadora do espírito; o trabalho assumiu-se como a nova "fonte privilegiada de certezas inquestionáveis” (Gorz, 1989a, p. 112). Nas palavras de Gorz (1989a, p. 118),

[...] o trabalho disciplina e ordena a vida, protege os indivíduos do colapso das certezas normativas e da responsabilidade de assumir o controle das suas vidas. As suas vidas já estão inteiramente prefiguradas. O trabalho é uma barreira protetora [...]. As questões acerca do significado e da finalidade da vida estão resolvidas de antemão: uma vez que não há espaço na vida do trabalhador para algo mais do 
que trabalhar para ganhar dinheiro, o dinheiro é o único objetivo possível. Na ausência de tempo para viver, o dinheiro é a única compensação para o tempo perdido, para uma vida arruinada pelo trabalho. O dinheiro simboliza tudo aquilo que trabalhador não tem, não é e nunca poderá ser em virtude dos constrangimentos impostos pelo trabalho.

\section{Nesse contexto,}

A medição quantitativa enquanto substituto do juízo de valor racional confere a segurança moral suprema e o conforto intelectual: o Bom torna-se mensurável e calculável; as decisões e os juízos morais podem ser derivados da implementação de um procedimento de cálculo impessoal, objetivo, quantificador e os sujeitos individuais não têm de suportar o fardo com ansiedade e incerteza: 'é virtuoso ganhar dinheiro’ (Gorz, 1989a, p. 121).

A produção tradicional regida pelo princípio da suficiência cedeu lugar, com o advento da sociedade moderna, à produção mercantil regida pelo princípio da maximização. Na sociedade do trabalho, a racionalidade instrumental, quantificadora, orienta a conduta e as preferências humanas em todas as esferas: "mais é melhor, $[\ldots]$ qualquer que seja o conteúdo concreto [...] destas quantidades crescentes.” (Gorz, 1989a, p. 119, grifo do autor). No modo de produção capitalista,

[...] o crescimento ilimitado é imprescindível a todos os níveis: enquanto insatisfação [...] e desejo por 'mais' no nível individual; enquanto exigência de uma maximização ilimitada no nível dos capitais parciais; enquanto exigência de um crescimento perpétuo no nível sistêmico; enquanto valorização ideológica da performance crescente (da velocidade, do poder das máquinas, do tamanho das fábricas, da altura dos edifícios, da produtividade agrícola e assim por diante) no nível da civilização. Isto pode ser aferido claramente pela maneira como a palavra 'crescimento' é pronunciada: ela está imbuída de um juízo de valor, designando o melhor e o mais elevado dos objetivos. O seu conteúdo é totalmente imaterial, apenas a taxa [de crescimento, NM] interessa [...]. O valor emocional, quase religioso que é atribuído à palavra não é o resultado do raciocínio, mas de um juízo normativo $a$ priori. (Gorz, 1989a, p. 120-121, grifo do autor)

Pode-se concluir que, em Gorz (1989a, p. 121), a racionalidade econômica e o capi- talismo são concomitantes e coextensivos. O capitalismo constitui o domínio da racionalidade econômica liberta de quaisquer constrangimentos de ordem moral ou estética, algo inédito na história humana. O trabalho corporiza essa ação econômica instrumental, sendo uma forma de atividade historicamente específica.

O autor define o trabalho como "a atividade levada a cabo: para outrem; em troca de um salário; de acordo com formas e horários estabelecidos pela pessoa que paga o salário; e com uma finalidade que não é escolhida pelo trabalhador" (Gorz, 1982, p. 1). Por outras palavras, o trabalho consiste:

a. na produção de bens e serviços;

b. para serem trocados como mercadorias;

c. na esfera pública;

d. num período de tempo quantificável e no nível de produtividade mais elevado possível (Gorz, 1989a, p. 138-139).

Em suma, não é a atividade concreta que interessa, mas apenas seu valor de troca (Gorz, 1989a, p. 137).

Na sociedade capitalista, é como trabalhadores assalariados que os indivíduos "adquirem uma existência social e uma identidade social (isto é, uma profissão)" (Gorz, 1989a, p. 13), ou seja, é apenas como trabalhador que o ser humano vê reconhecido o seu direito a existir. É precisamente em virtude de o trabalho assalariado ser

[...] o fator de socialização mais importante - mesmo para aqueles que o procuram, que se preparam para ele ou que não o possuem - que a sociedade industrial se vê a si mesma como uma 'sociedade de trabalhadores' e se distingue, nesse sentido, das formações sociais do passado" (Gorz, 1989a, p. 13-14).

\section{Reflexão Crítica}

Apesar do mérito de suas análises, que denunciam a naturalização das categorias capitalistas, a teoria gorziana da década de 1980 permanece ambígua e introduz, sub-repticiamente, uma ontologia: o trabalho, na Antigui- 
dade, é contraposto ao trabalho na Modernidade. Embora reconheça a diferença abissal entre a forma assumida pelo metabolismo com a natureza (e sua organização social) nas sociedades do passado e aquela específica ao capitalismo, Gorz continua, por vezes, a qualificar ambas as realidades sociais como trabalho.

Desse modo, seu pensamento é marcado por uma aporia relativamente ao conceito de trabalho: por um lado, é afirmado que o trabalho não existiu sempre, pelo que o capitalismo é a primeira "sociedade do trabalho"; mas, por outro lado, é acrescentado que o trabalho nem sempre existiu tal como se apresenta sob o capitalismo: "O trabalho não existiu sempre na forma como é entendido atualmente" (Gorz, 1982, p. 1, grifo do autor).

Ora, essa asserção aparentemente inocente permite fazer entrar pela porta do cavalo um entendimento trans-histórico do trabalho: se é verdade que o trabalho, tal como existe nas sociedades capitalistas, é uma invenção moderna, nas sociedades do passado existia outro tipo de "trabalho", com outras características. O trabalho é, assim, implicitamente equiparado à (re)produção material de todas as sociedades humanas ou, se quisermos, ao "trabalho concreto" de Marx.

A própria colocação do termo entre as^ pas revela o desconforto sentido por Gorz em స्. qualificar a atividade produtiva do passado \ั como trabalho: "Não pode existir nenhuma so这 ciedade, nenhuma vida, sem «trabalho», mas थ nem todas as sociedades e vidas são baseadas no trabalho." (Gorz, 1989a, p. 153). Todavia, Gorz não é capaz, ainda, de dar o passo lógico e decisivo, que seria reconhecer que o trabalho tout court é uma realidade especificamente moderna, a forma de que se reveste a atividade produtiva numa sociedade econômica.

Será proveitoso, nesse âmbito, recuperar o conceito marxiano de "subsunção real" do trabalho ao capital (Marx, 1975, p. 79), que se refere à criação histórica de um processo de produção material - em termos técnicos, tecnológicos e organizacionais - especificamen- te capitalista. Segundo Botelho (2009, p. 70), "[...] a forma social capitalista se inscreve na matéria, cria uma técnica adequada a seu objetivo [...] de valorização do valor".

As modalidades concretas do trabalho são coagidas por um padrão objetivo de produtividade: a configuração técnico-científica do trabalho espelha a necessidade de "[...] produzir um objeto empregando somente o tempo de trabalho [socialmente, NM] necessário sob as condições sociais gerais de produção." (Marx, 1988, p. 197, grifo do autor). Pela primeira vez na história, a duração temporal do processo produtivo converte-se no "[...] único critério para a avaliação e comparação das diferentes atividades" (Jappe, 2006, p. 48), pois aquilo que está em jogo é, acima de tudo, a criação de valor.

Assim, a subsunção real significa que o próprio processo de (re)produção material (concreto) é revolucionado, assumindo uma forma especificamente capitalista e, portanto, inaudita na história da Humanidade. É completamente impossível falar de um suposto trabalho concreto supra-histórico, materialmente idêntico em todas as sociedades. ${ }^{14}$

A ambiguidade da teoria gorziana será finalmente superada com a publicação de $C a$ pitalismo, Socialismo, Ecologia, em 1991. Nesse livro, Gorz reconhece, de modo inequívoco, a historicidade do trabalho:

A noção de trabalho é uma invenção da modernidade ou, mais precisamente, do capitalismo industrial. Enquanto a produção mercantil permaneceu marginal e a maior parte das necessidades era satisfeita através da produção doméstica e da economia aldeã, a noção de 'trabalho' enquanto tal [...] não se pôde afirmar. As pessoas 'produziam', 'construíam', e 'preparavam' coisas; elas 'labutavam', 'penavam', 'esforçavam-se arduamente' e 'exerciam' uma variedade de 'ocupações' específicas que não possuíam qualquer medida comum no contexto da comunidade doméstica. [...] A noção de trabalho assumiu o seu significado atual apenas quando a produção e o consumo mercantis adquiriram precedência sobre a produção para uso

${ }^{14}$ Cf. Bischoff (1995) e Homs (2012) para uma crítica concludente desse entendimento materializante e trans-histórico do trabalho. 
próprio. Então, o ‘trabalho’ tornou-se o nome de uma atividade fundamentalmente diferente das atividades de subsistência, de reprodução, de manutenção e de cuidados efetuadas na esfera doméstica. [...] O 'trabalho' é uma atividade paga [...] efetuada no domínio público e que aparece aí como uma performance mensurável, permutável e intercambiável; como uma performance que possui valor de uso para os outros e não apenas para os membros da comunidade familiar que a levam a cabo: para os outros em geral (Gorz, 1994, p. 53, grifo do autor).

O trabalho é, portanto, uma "categoria socio-histórica" e não uma categoria "antropológica” (Gorz, 1994, p. 54, grifo nosso). O trabalho - como conceito e como realidade social - simplesmente não existia nas sociedades pré-capitalistas. Num artigo de 2002, intitulado "Ecologie et Socialisme", Gorz é capaz de discernir o advento do trabalho como categoria bipartida: a noção de produção material em geral, isto é, o "trabalho concreto" de Marx, é indissociável da constituição histórica da atividade social ponente de valor, isto é, o "trabalho abstrato” de Marx. Na ótica de Gorz (2002, p. 74, grifo do autor),

O trabalho tal como nós o entendemos hoje em dia apenas nasceu com o capitalismo manufatureiro, seguidamente industrial. [...] Nas sociedades pré-capitalistas e pré-modernas, as atividades eram classificadas segundo a sua determinação particular e a sua posição hierárquica, não lhes sendo reconhecida nenhuma outra medida comum, nenhuma outra essência. [...] O conceito de trabalho tal como aparece em Hegel foi, portanto, uma revolução filosófica [...]. Ele designava a essência comum à totalidade das atividades mediante as quais o sujeito se inscreve e se objetiva na materialidade do mundo [...]. Ele designa a essência comum do conceber, do fazer, do fabricar e do agir que até então eram categorias incomensuravelmente distintas. [...] Este conceito [...] apenas pôde surgir [...] quando o capitalismo manufatureiro deu origem a um proletariado de trabalhadores sem ofício, nem estatuto social e profissional, fornecedores de trabalho em geral, trabalho em si, trabalho sem [qualquer] determinação particular. Com este proletariado [...] aparece pela primeira vez aquilo que Marx chamará de trabalho abstrato, trabalho-mercadoria, mensurável, quantificável, indiferente ao seu conteúdo, desvinculável dos indivíduos intercambiáveis que o realizam.
Em suma, não é possível falar de trabalho concreto na ausência de trabalho abstrato e vice-versa. O trabalho é justamente a unidade necessária (e contraditória) desses dois polos. O modo de produção capitalista é simultaneamente a forma de (re)produção material peculiar de uma sociedade particular e um processo de valorização, ou seja, de produção de uma forma de riqueza abstrata, historicamente específica: o valor econômico. $O$ trabalho encerra em si a determinação binomial da produção capitalista.

\section{DOMINIQUE MÉDA: a emergência simultânea do trabalho e do indivíduo}

Dominique Méda (2010, p. 20) salienta que a "concepção comum" da esmagadora maioria das correntes teóricas do século XX é a noção do trabalho como categoria transhistórica, antropológica. O trabalho é entendido como "[...] uma invariante da natureza humana” (Méda, 2010, p. 18). Uma grande parte dos cientistas sociais projeta "[...] sobre o nosso passado mais antigo categorias profundamente modernas", cometendo um "erro grave ao imaginar os antigos [...] sob a figura do trabalhador" (Méda, 2007, p. 17).

Ora, na perspetiva da autora, o trabalho está longe de ser uma realidade social autoevidente, pois, no seu conceito contemporâneo, ele é "[...] um conglomerado de camadas de significado diferentes que foram sendo depositadas nos últimos séculos e que, de certa maneira, se sedimentaram, fazendo esquecer o seu caráter histórico" (Méda, 2007, p. 17). Se é verdade que os seres humanos "sempre tiveram que confrontar a natureza para sobreviver e transformar suas condições de vida", nas sociedades pré-capitalistas, “[...] essas atividades não pertenciam a uma só categoria e não fundamentavam a ordem social.” (Méda, 2007, p. 18).

O trabalho é "uma categoria profundamente histórica cuja invenção apenas deveio necessária numa época específica” (Méda, 
2010, p. 31). Nesse sentido, Méda preconiza que é mister "interrogar-nos acerca do nascimento, evolução e, de um modo mais geral, da genealogia das sociedades baseadas no trabalho. Quando é que elas apareceram? Por quê? Em resposta a que contexto, a que questões, a que problema e em nome de quê?" (Méda, 2010, p. 29).

\section{As Atividades Produtivas nas Sociedades Pré-Capitalistas}

Hoje em dia, "o trabalho é o fundamento dos laços sociais e o modo de expressão privilegiado dos indivíduos" (Méda, 2010, p. 31). Porém, nas sociedades pré-modernas, em que não existia trabalho, essas funções eram "desempenhadas por outro tipo de relações sociais" (Méda, 2010, p. 31). As sociedades pré-capitalistas eram regidas por "lógicas simultaneamente sagradas e sociais", de maneira que a organização social era "estruturada em torno de princípios transcendentes” (Méda, 2010, p. 32).

As sociedades primitivas não são estruturadas pela (re)produção material (Méda, 2010, p. 32). Os estudos antropológicos permitem afirmar que não existia, nessas sociedades, um termo com um significado idêntico n ao do "trabalho" moderno (Méda, 2010, p. 33) 亏ั e muitas delas "não possuíam sequer uma paब lavra para distinguir as atividades produtivas de outros comportamentos humanos" (Méda, ¿ 2010, p. 33). É possível encontrar palavras que P designam o esforço ou o sofrimento, mas que não estão associadas a um tipo específico de atividades, mormente aquelas ligadas à subsistência (Méda, 2010, p. 34).

O tempo dedicado às "atividades de reprodução" é bastante reduzido, porquanto as necessidades são igualmente limitadas (Méda, 2010, p. 34). Ademais, "as atividades de subsistência são permeadas por outras lógicas" (Méda, 2010, p. 34); pode falar-se de "atividades sociais situadas a meio caminho entre o esforço e o jogo" (Méda, 2010, p. 35). A reprodu- ção material da sociedade está completamente imbricada no sagrado e no divino: "entre os Trobriandeses, o mago dos jardins controla o lavor dos homens e as forças da natureza. A magia exerce um papel coordenador, regulador e diretor sobre o cultivo dos campos." (Méda, 2010, p. 37).

De acordo com Méda (2010, p. 37-38),

[...] a noção de trabalho não existe onde as necessidades naturais são limitadas, onde o indivíduo ainda não irrompeu enquanto tal e onde as trocas econômicas ainda não se desenvolveram. [...] Estas sociedades são estruturadas por outras lógicas: elas possuem uma relação particular com a exterioridade (a tradição, a natureza, os deuses...) que determina as regras sociais e as torna suficientemente 'fortes' para assegurar a coesão da sociedade. Elas não necessitam de outros tipos de regulação. Neste contexto, a ação conducente à subsistência [...] não dá origem a qualquer diretiva particular ou hierarquia social. [...] Os fatos sociais que estruturam estas sociedades não possuem uma natureza econômica. [...] Eles baseiam-se em laços de sangue e de parentesco, em símbolos, em certas relações com a natureza, com a tradição, etc.

Em suma, as sociedades tribais são "sociedades pré-econômicas” (Méda, 2007, p. 18). O ganho pessoal não desempenha qualquer papel motivador na ação do homem primitivo (Méda, 2010, p. 35). Os bens produzidos não têm como finalidade a troca, visto que os intercâmbios não possuem uma natureza econômica, mas assentam, ao invés, na dádiva e na reciprocidade (Méda, 2010, p. 36).

Na Grécia Antiga, existiam "ofícios, atividades, tarefas", mas não existia o termo "trabalho" (Méda, 2007, p. 19), "compreendido como noção unívoca que engloba os diferentes ofícios ou os diferentes 'produtores"” (Méda, 2010, p. 41, grifo nosso). Por outras palavras, as atividades eram "classificadas em categorias irredutivelmente diversas” (Méda, 2007, p. 19). ${ }^{15} \mathrm{O}$ estatuto associado às atividades era

${ }^{15}$ Chamoux (2001, p. 62) realça que existiam palavras que significavam atividade penosa ou esforço ("ponos"), tarefa ou obra ("ergon"), conhecimento técnico ou saber-fazer ("tecnhnê"), mas não um termo unívoco similar ao "trabalho" moderno 
hierarquizado de acordo com o grau de dependência que elas acarretavam:

[N]o nível mais baixo, estava a atividade dos escravos, seguida pela dos artesãos e pela dos mendigos (os quais pertencem à mesma categoria, dado que vivem somente [...] da retribuição recebida de outrem). As atividades que hoje chamaríamos laboriosas (ainda que não se encontrassem subsumidas no mesmo conceito) não eram desprezadas em si mesmas, mas, sobretudo, porque implicavam a servidão ${ }^{16}$ (Méda, 2007, p. 19-20).

Na sociedade grega, não é a reprodução material que fundamenta o laço social (Méda, 2010, p. 41), mas as relações de natureza política (Méda, 2010, p. 47). Méda (2010, p. 47-48). explica por quê: "o laço político baseia-se na igualdade e na identidade, ou ainda na philia, traduzida usualmente por amizade", enquanto "o laço material obriga os indivíduos dotados de capacidades diferentes a inserirem-se em relações de serviço e dependência que estão nos antípodas do laço político."

A esfera da necessidade doméstica o oikos - é o lócus das atividades (servis) de subsistência realizadas pelos escravos e pelas mulheres (Méda, 2010, p. 41 e 43). Os cidadãos - os homens livres - são eximidos dessas atividades indignas, penosas (Méda, 2010, p. 44 ), para poder se dedicar às atividades verdadeiramente livres, de foro moral e político (Méda, 2007, p. 19). Na ótica da filosofia grega, "o homem é um animal racional e a sua tarefa é desenvolver essa razão que faz de si homem e que o torna parecido com os deuses." (Méda, 2010, p. 48).

Em Aristóteles, por exemplo,

[...] as atividades humanas são valorizadas em função da sua maior ou menor semelhança com a imobilidade e a eternidade. Daí a valorização do pensamento, da theoria, da contemplação ou, em termos mais gerais, da ciência, seja ela matemática ou filosófica, na medida em que ela tem como objeto as essências ou as figuras imutáveis [...]. Esta atividade

${ }^{16}$ Assim, as atividades agrícolas, por exemplo, não são desprezadas porquanto os agricultores são capazes de assegurar autonomamente sua própria sobrevivência (Méda, 2010, p. 42).
[...] é exercida pela alma ou pela razão e não pelo corpo. Duas outras atividades são igualmente valorizadas [...]: a atividade ética e a atividade política. A primeira, também denominada praxis, designa as atividades que são um fim em si mesmas [...]: elas [...] não são instrumentos a serviço de outro fim. A segunda permite ao homem exercer a sua humanidade, isto é, a razão e a palavra, e envolve o aperfeiçoamento contínuo daquilo sem o qual o homem só não é nada: a cidade. (Méda, 2010, p. 40-41)

Pode-se concluir que a maximização da produção, o valor econômico e a transformação da natureza são noções alheias ao mundo grego (Méda, 2007, p. 19). Nesse contexto, "as atividades comerciais eram [...] condenadas" (Méda, 2007, p. 19) e não era o intercâmbio que ancorava os laços sociais, mas sim a política - o campo de ação dos cidadãos (Méda, 2007, p. 20).

Na Roma Antiga, a representação das atividades produtivas e de subsistência não sofre alterações significativas (Méda, 2010, p. 50). São igualmente os escravos que se encarregam das atividades penosas e desagradáveis (Méda, 2010, p. 50). Em Cícero, por exemplo, ressurge a oposição entre atividades servis, isto é, "efetuadas sob a dependência de outrem", e atividades dos homens livres, que são um fim em si mesmas (Méda, 2010, p. 50). O otium - o lazer - é valorizado pelos romanos (Méda, 2007, p. 20), ao contrário do negotium, que engloba as atividades pagas com vistas a obter os meios de subsistência e igualmente as atividades comerciais (Méda, 2010, p. 50-51).

No seio do Império romano, vai-se assistir à difusão do cristianismo e da sua "nova imagem do homem” (Méda, 2010, p. 51-52). Santo Agostinho, no século V, opera uma mudança significativa no conceito de otium: ele deixa de ser "sinônimo de ócio estudioso, cultivado e louvado, tornando-se sinônimo de preguiça" e, portanto, algo negativo (Méda, 2007, p. 20). A atividade produtiva começa, pouco a pouco, a ser valorizada, justamente em virtude de seu caráter penível: como penitência (Méda, 2010, p. 57), expiação e mortificação da carne. 
O labor agrícola e a opus artesanal aparecem como o melhor antídoto face aos malefícios da ociosidade: ambos permitem ocupar o corpo e libertar o espírito para a oração (Méda, 2010, p. 57). Note-se que o termo opus deixa de estar limitado à ação divina - a opus Dei - e começa a ser empregado para caraterizar a atividade humana (Méda, 2007, p. 20). Nos séculos VIII e IX, ocorre uma enorme valorização das atividades agrícolas (Méda, 2010, p. 59), começando a se formar uma "classe homogênea": "aquela dos laboratores, constituída pelos camponeses e, depois, englobando [também, NM] os artesãos" (Méda, 2010, p. 59). ${ }^{17}$

Embora, durante a Idade Média, existisse um forte tabu associado ao dinheiro e às atividades lucrativas, nos séculos XII e XIII, o número de ofícios considerados ilícitos pela Igreja reduz-se substancialmente (Méda, 2010, p. 59). É São Tomás quem codifica essa nova realidade, propondo a noção de "utilidade comum”, que justifica a realização de uma dada atividade bem como a sua remuneração (Méda, 2010, p. 60).

Para além disso, ao longo da era medieval a diferença entre labor e opus vai esbater-se pro-

17 Todavia, Manfred Bischoff(Bischoff, 1995, p. 61) relembra que a racionalidade econômica está ausente da síntese social feudalista. Na sociedade medieval, "a maior parte [...] dos bens são produzidos e 'intercambiados' no quadro de relações hierárquicas de dependência pessoal." (Bischoff, 1995, p. 59). Existem laços de vassalagem no seio

ㄱ da elite latifundiária e guerreira e laços de servidão entre a $\dot{\mathrm{i}}$ nobreza e os camponeses (Bischoff, 1995, p. 59). A natureza rígida dos laços sociais, fundada na religião, estabelece ¿ uma rede de "[...] obrigações e contraobrigações" especí-

๗ ficas que cada uma das classes deve cumprir, de acordo

$\infty$ com o costume e a tradição, para respeitar escrupulosa-

$\stackrel{\infty}{\infty}$ mente "a ordem normativa transcendente" (Bischoff, 1995,

§่ p. 60). Assim, "a atividade não se apresenta ao indivíduo

尔 [...] como uma realidade exterior a si mesmo, como uma prestação de que ele pode dispor livremente e que tem [...]

2. um valor exclusivamente instrumental. A atividade é in-

¿̇ dissociável do sujeito, pois ela lhe confere uma dimensão

¿ essencial de sua identidade estatutária como membro ati-

- vo da comunidade de fiéis que cumpre sua 'vocação'. Em

ค todas as circunstâncias, o sujeito e sua atividade perma-

$>$ necem ligados, unidos, às condições concretas da socie-

ث dade." (Bischoff, 1995, p. 62). Por essa razão, as atividades

- feudais são serviços - realizados "num contexto societal

$\stackrel{\pi}{\geq}$ de normas culturais interiorizadas e concretas, e de rela-

స్ ções [sociais, NM] com caráter interpessoal e inigualitário"

(Bischoff, 1995, p. 69) - que não devem ser confundidos

I com o trabalho moderno, realizado "num contexto socie-

ful de normas institucionais exteriores e abstratas, e de

- relações [sociais, NM] com caráter impessoal e igualitá-

rio, exercendo direitos e obrigações definidas pelo sistema

da propriedade privada e do contrato jurídico" (Bischoff,

ङ 1995, p. 69). gressivamente (Méda, 2010, p. 54). Esse processo culminará, no dealbar da modernidade, na emergência do embrião do trabalho: o conceito unívoco de "uma categoria de atividades árduas ou que se destinam a satisfazer às necessidades" (Méda, 2007, p. 21). ${ }^{18}$ Em síntese,

[...] a Idade Média vai ser o palco de uma lenta conversão dos espíritos e das práticas. Pouco a pouco, sob a pressão [...] da necessidade de definir as normas de vida - em particular monacais - os Pais da Igreja e os teóricos vão promover uma nova ideia do trabalho. É somente no final da Idade Média que a teoria e as práticas mudarão a ponto de permitirem a eclosão de uma modernidade centrada no trabalho (Méda, 2010, p. 53-54).

Méda defende a mesma ideia em outro de seus textos:

No decurso da Idade Média operam-se, lentamente, as transformações que conduzirão no século XVIII à invenção, na sua unicidade, da categoria trabalho, assim como ao reconhecimento do seu valor. ...] Pouco a pouco, a palavra 'trabalho' vem a ser entendida como atividade, fonte de rendimentos e, portanto, devém sinônimo de atividade produtiva. (Méda, 2007, p. 21, grifo do autor)

Deve-se salientar, ainda, que a consideração inaudita pela produção material de riquezas, que inaugura a Modernidade, não se justifica só pela ação da Igreja, mas igualmente pela "[...] ascensão social de certo número de classes [...] que querem obter seu reconhecimento: artesãos, comerciantes, técnicos" (Méda, 2010, p. 60).

\section{A Invenção do Trabalho}

No final do século XVIII, assiste-se a uma alteração profunda da natureza das relações sociais e de suas representações teóricas. A tolerância das atividades comerciais, no final da Idade Média, dá lugar a um entendi-

${ }^{18}$ Serge Latouche (2005, p. 72) lembra que o termo "tripaliare" remete, originalmente, para a tortura com recurso ao "tripalium", um instrumento formado por três estacas de madeira. Assim, quando a palavra passou a ser utilizada para designar as atividades produtivas, ela ainda evocava "o sofrimento e inclusive a humilhação". 
mento delas como atividades virtuosas (Méda, 2010, p. 63). O desejo de enriquecimento, previamente condenado, passa a ser celebrado e devém o objeto de estudo de uma nova ciência: a economia politica (Méda, 2010, p. 63). Nesse contexto, o trabalho assalariado torna-se “onipresente” (Méda, 2010, p. 64), porquanto contribui decisivamente para o aumento da riqueza de uma nação - para a criação de valor econômico (Méda, 2010, p. 65).

A partir de Adam Smith, a atividade produtiva é definida de forma abstrata: o trabalho é uma "substância homogênea idêntica [...] e infinitamente divisível" (Méda, 2010, p. 65). O tempo de trabalho é aquilo que possibilita a comparação das quantidades de trabalho contidas nas mercadorias e, assim, sua troca (Méda, 2010, p. 66); as atividades heterogêneas são, pois, equiparadas, através do tempo, que é a categoria mais "abstrata e homogênea" existente (Méda, 2010, p. 66). Méda realça que "o trabalho não é [...] apenas como o tempo, ele é o tempo: este é sua matéria-prima, seu componente derradeiro” (Méda, 2010, p. 6667 , itálico no original).

Foi a ciência econômica que inventou o conceito de trabalho, conferindo-lhe um significado uniforme, instrumental e temporal (Méda, 2010, p. 68). Por outras palavras, os economistas “[...] inventaram e unificaram o termo trabalho, isto é, englobaram, na mesma categoria, atividades [...] que eram [...] percebidas e classificadas em registos bastante diferentes: a lavoura dos campos, o artesanato..." (Méda, 2010, p. 71).

Todavia, Méda se apressa a acrescentar que os economistas se limitaram a traduzir conceptualmente o nascimento do trabalho como realidade social peculiar. Foram "circunstâncias históricas” específicas que permitiram "inventar o trabalho como capacidade [abstrata, NM] suscetível de ser exercida livremente pelo indivíduo" e, portanto, de "ser pensada de certa maneira” (Méda, 2010, p. 111). O trabalho surge simultaneamente como abstração real e como abstração conceptual: "este conceito famoso ou esta realidade famosa não existiam anteriormente, nem em si, nem como representação. [...] [O] século XVIII inventou o trabalho como categoria homogênea e como fator de crescimento da riqueza." (Méda, 2010, p. 72). Na perspetiva de Méda (Méda, 2007, p. 21),

\section{[...] é possível falar 'do' trabalho a partir do momento em que um certo número de atividades que não es- tavam relacionadas até então, que eram regidas por lógicas irredutivelmente diversificadas, se tornam suficientemente homogêneas para serem reunidas num único termo. [...] [O] trabalho é antes de tudo uma unidade de medida, um quadro de homogenei- zação de esforços, um instrumento que permite que as diferentes mercadorias sejam comparáveis. A sua essência é o tempo. A noção de trabalho encontra a sua unidade, mas em detrimento do conteúdo con- creto das atividades que abarca: o trabalho é cons- truído, instrumental, abstrato. Também é mercantil e desvinculável do indivíduo.}

O modo de produção capitalista introduziu uma gigantesca ruptura na história da $\mathrm{Hu}-$ manidade, sendo a primeira sociedade do trabalho (Méda, 2010, p. 7). O advento histórico do trabalho é indissociável da transformação do ser humano - ou, mais exatamente, da sua energia física e mental - em mercadoria. Ao serem expropriados de suas terras, os camponeses foram despojados dos meios de subsistência. A única coisa que lhes restou foi a célebre "propriedade de si", isto é, o poder de dispor livremente da sua força de trabalho, teorizada por Locke (Méda, 2010, p. 73). Segundo Méda, "o trabalho aparece como esta energia, propriedade do indivíduo" (Méda, 2007, p. 21).

A força de trabalho assume-se, então, como uma mercadoria sui generis. Os indivíduos formalmente livres podem alienar uma parcela de seu tempo em troca de um salário (Méda, 2010, p. 72-73) e, desse modo, assegurar um conjunto de direitos, mormente o direito de sobreviver: "O direito à vida confunde-se [...] com o direito ao livre exercício de um trabalho." (Méda, 2010, p. 129). Méda salienta que estamos na presença de uma realidade deveras peculiar: "existe uma parte da atividade humana que pode ser desvinculada do seu 
sujeito $[\ldots]$ e que pode ser alugada ou vendida." (Méda, 2010, p. 75-76).

O trabalho - abstrato, assalariado e mercantil (Méda, 2010, p. v) - é a categoria estruturante da sociedade econômica moderna:

O trabalho é a atividade que produz exclusivamente mercadorias, logo objetos suscetíveis de serem trocados $[\ldots]$. A troca aparece como o centro da sociedade $[\ldots]$ e o trabalho como a condição daquela. [...] [O] trabalho deveio a razão da nova sociedade. Ele é ao mesmo tempo terrivelmente concreto (a sua essência é a fadiga, o esforço, a pena, sendo este o preço a pagar pela participação na vida social) e eminentemente abstrato (o trabalho é o instrumento de comparabilidade de todas as coisas). Tudo se passa como se o laço social fosse construído graças à venda desta substância individual que é o esforço. O trabalho é, na verdade, a nova relação social que estrutura a sociedade. Neste sentido, [...] ele responde a uma necessidade e constitui uma solução. (Méda, 2010, p. 77-78)

Méda defende que o trabalho foi uma resposta à "[...] decadência dos sistemas tradicionais de 'legitimação' [...], que explicam o sentido do mundo, o papel dos homens e da sociedade e estabelecem as obrigações" sociais (Méda, 2010, p. 265-266) e ao principal resultado dessa decomposição: a emergência histórica do indivíduo. Com efeito, é possível identificar o surgimento concomitante "da econo^ mia como domínio específico da realidade e do : veis pela ciência, de modo que Deus desaparece gradualmente de cena (Méda, 2010, p. 83).

Segundo Méda, esse paralelismo não foi acidental. No século XVII, assistiu-se à rutura definitiva com as "representações clássicas do mundo", nomeadamente à superação da visão geocêntrica (Méda, 2010, p. 81). Galileu, Newton e Descartes instauram "uma nova imagem da natureza, do homem e da relação que os une" (Méda, 2010, p. 82). O mundo é regido por eis naturais matemáticas universais, explicá-

O colapso do geocentrismo trouxe consigo, portanto, a derrocada das "relações tradicionais" entre o homem e a natureza (Méda, 2010, p. 82) e, mais importante, colocou em causa as representações e a ordem sociais (Méda, 2010, p. 83). As certezas conferidas pela religião, como princípio unificador da sociedade medieval, foram abaladas; o ser humano emancipa-se dos laços de dependência pessoal, mas sua vida perde o significado, a segurança e o sentimento de pertença, conferidos pela ordem tradicional imutável (Méda, 2010, p. 85-86).

A nova cosmovisão pode ser sintetizada da seguinte maneira: "de um lado, uma natureza desencantada, sem qualidades [...] e, de outro lado, um sujeito pensante, livre, certo da sua existência, consciente de ser diferente e estar separado dessa natureza que o confronta doravante." (Méda, 2010, p. 88-89, grifo nosso). É nesse contexto que a crença religiosa vem a ser gradualmente substituída por relações econômicas utilitaristas. $\mathrm{O}$ trabalho surge como o novo princípio unificador da sociedade e como a nova identidade do ser humano que deveio, pela primeira vez, indivíduo: sujeito de direito e de deveres, assente na figura esquizoide do trabalhador-cidadão (Méda, 2010, p. 89). Nas palavras de Méda (2010, p. 208-209),

O trabalho constituiu uma solução face à questão do aparecimento do indivíduo na esfera pública e aos riscos de perturbação da ordem social que esta comportava. Ele foi o meio privilegiado de integração do indivíduo no todo social e, portanto, o meio de assegurar uma certa automaticidade da regulação social. Em certa medida, enquanto atributo [comum, NM] de todos os indivíduos, o trabalho substituiu as antigas ordens [sociais, $\mathrm{NM}$ ] assentes em hierarquias naturais ou tradicionais e fundou um novo princípio de ordem [social, NM], baseado nas capacidades [humanas, $\mathrm{NM}$ ] e passível de engendrar uma nova hierarquia social. Ele foi, portanto, o meio de emancipação do indivíduo, o que é comprovado pelas técnicas fundamentalmente individualistas que o regem, em particular a economia, que representa a tradução concreta de uma visão contratualista da sociedade. Trabalho, economia e visão contratualista são concomitantes.

O trabalho é uma categoria existencial suscetível de conferir (pelo menos em parte) ao pensamento e à ação humanas o sentido que haviam perdido (Méda, 2010, p. 85). Ele é 
a resposta à "necessidade de construir [...] novos modos de regulação” (Méda, 2010, p. 266), a solução encontrada para o "fundamento da [nova, NM] ordem social” (Méda, 2010, p. 90). O trabalho constitui uma categoria capaz de ancorar a unidade social e de organizar as relações de caráter econômico (Méda, 2010, p. 90). O trabalho assalariado e o seu corolário lógico, a troca mercantil, são responsáveis pela síntese social capitalista (Méda, 2010, p. 91).

A sociedade econômica foi capaz, então, de erigir uma ordem social sólida no lugar da ordem tradicional religiosa em decomposição (Méda, 2010, p. 94). O nascimento do capitalismo está associado à mudança do princípio orientador da humanidade: o afastamento do sagrado colocou os seres humanos "ao serviço de uma ordem racional mundana” (Méda, 2010, p. 320). Por conseguinte, “a produção deveio o centro da vida [...] social e o trabalho o meio de expressão privilegiado" dos indivíduos (Méda, 2010, p. 320).

\section{FRANÇOISE GOLLAIN: aborda- gem historicista versus abordagem essencialista}

Françoise Gollain reconhece a influência primordial de André Gorz em sua "reflexão crítica sobre o trabalho" (Gollain, 2000, p. 7). Aliás, não será exagero entender Gollain como uma pensadora "gorziana”, fazendo fé nas suas palavras: Gorz “é, sem dúvida, o autor cujas teses exerceram uma influência mais decisiva sobre minhas opções intelectuais e minhas escolhas existenciais" (Gollain, 2008, p. 545); Gorz era o seu "mestre e amigo" (Gollain, 2008, p. 547).

Porém, apesar dessa influência marcante, a autora foi capaz de propor um conjunto de reflexões teóricas francamente originais. Segundo Gollain, as teorias acerca do trabalho, nas ciências sociais contemporâneas, podem ser, grosso modo, agrupadas em dois campos: o essencialista e o historicista (Gollain, 2000, p. 109).

A abordagem essencialista procura evi- denciar as (supostas) "continuidades históricas" no que diz respeito à forma revestida pelas atividades produtivas, com vistas a destilar um “conteúdo permanente”, invariável, que seria $o$ trabalho tout court (Gollain, 2000, p. 111). Ora, na ótica da autora, qualquer tentativa de propor um "conceito rigoroso de trabalho enquanto invariante antropológica” encontra inevitavelmente obstáculos sérios e acaba por enredar-se em contradições (Gollain, 2000, p. 113). Inúmeros estudos antropológicos revelam "as dificuldades semânticas que se colocam à tentativa de subsumir uma variedade de atividades sob o mesmo termo", demonstrando que, "nas sociedades pré-capitalistas, o trabalho não podia funcionar como conceito" (Gollain, 2000, p. 113, grifo do autor) nem como realidade social:

\footnotetext{
[N]as sociedades pré-capitalistas, [...] as atividades produtivas estão incrustadas em outras práticas sociais. Elas podem comportar uma forte dimensão ritual, religiosa ou estética. Esta imersão no social é largamente confirmada pelo fato de que, tal como não há uma separação face às outras atividades, não existe um estatuto separado de trabalhador. (Gollain, 2001, p. 178-179)
}

Nesse sentido, o mundo ocidental moderno representa uma "rutura real" na história das sociedades humanas (Gollain, 2000, p. 111, grifo do autor). A revolução industrial - que acarretou a "artificialização" das relações entre o homem e a natureza e das próprias relações sociais (Gollain, 2000, p. 38) - e a constituição simultânea de um sistema de mercado autorregulado engendraram uma nova sociedade, "assente numa ordem técnica exterior aos indivíduos, constritiva e objetiva" (Gollain, 2000, p. 39).

A sociedade moderna instaura um "processo global de racionalização" e de diferenciação, expresso nomeadamente na autonomização da esfera da produção face aos demais campos da vida (Gollain, 2000, p. 39). O trabalho surge intimamente associado a essa construção de uma esfera econômica autônoma e à correspondente mercadorização das relações sociais: 
A noção de trabalho é uma noção moderna que nasce com o capitalismo industrial [...]. Até então, grande parte das necessidades era satisfeita através da produção para uso próprio, no contexto da comunidade doméstica e aldeã, que compreendia uma multiplicidade de atividades (de subsistência) que não eram avaliadas nem intercambiadas. À medida que a produção e o consumo mercantis perdem o seu caráter marginal, o ‘trabalho’ efetuado no espaço público aparece como uma prestação mensurável e remunerável porque ela adquire um valor de troca [...]. Este trabalho em geral é o trabalho abstrato de Marx (Gollain, 2000, p. 111).

Somente no capitalismo, portanto, é que “[...] a diversidade das atividades humanas se encontra absorvida numa única categoria abstrata em resposta ao imperativo de mensuração e de venda no mercado" (Gollain, 2001, p. 181). O trabalho é o instrumento de uma nova maneira de pensar e de agir (Gollain, 2000, p. 17) que substitui os sistemas sociais "estruturados pela religião” (Gollain, 2000, p. 22).

A partir do que foi exposto, é evidente que o trabalho não pode ser apreendido em termos estritamente materiais, como pretende a abordagem essencialista. $\mathrm{O}$ trabalho não é primariamente o "exercício de uma atividade produtiva” (Gollain, 2001, p. 186), mas uma relação social específica (Gollain, 2001, p. 182) que estrutura as sociedades contemporâneas (Gollain, 2000, p. 158). O trabalho é ڤิ a "relação social dominante da modernidade" ( Gollain, 2001, p. 182, grifo do autor) em virtude de dois aspectos interligados. troca de um salário" converteu-se no "recurso maior ou único de grande parte da população" ¿. para assegurar sua subsistência (Gollain, 2001, p. 182). Em segundo lugar, o trabalho é direta\& mente responsável pela síntese social capita$\therefore$ lista, ou seja, refere-se às atividades humanas levadas a cabo com o intuito de promover a acumulação de capital (Gollain, 2001, p. 182). Isso pressupõe que o trabalho seja uma atividade "quantificável, desvinculada da pessoa do trabalhador" (Gollain, 2000, p. 67). O trabalho abstrato é a categoria-chave para enten- der a sociabilidade moderna fundamentada na produção de valor econômico:

[N]um sistema capitalista, em que a produção de valor é fundamental, todas as atividades são suscetíveis de serem transformadas em vetor de valor e, portanto, de devirem objeto de cálculo e de mensuração. Por consequência, quase todas as relações interpessoais, mesmo aquelas do quotidiano, são dominadas pela forma-valor do trabalho. Desta maneira, a centralidade do trabalho não significa apenas a obrigação de trabalhar, mas, sobretudo, a dominação do trabalho abstrato, isto é, aquela da valorização sobre a vida quotidiana: dominação da temporalidade do trabalho, a escola como dispositivo disciplinar preparatório, a subordinação das relações afetivas e familiares e a submissão das mulheres no interior da esfera doméstica (Gollain, 2000, p. 139, grifo do autor).

Em suma, o trabalho é uma categoria inserida num "contexto socio-histórico em que todos (ou quase todos) os bens e serviços possuem um valor mercantil" (Gollain, 2000, p. 158). Gollain (2000, p. 159) observa que "é impossível dar uma definição substantiva de trabalho" porque "não é a natureza [concreta, $\mathrm{NM}$ ] da atividade que define o trabalho [...], mas a sua inscrição na esfera mercantil”. Portanto, o trabalho é uma "categoria socio-histórica” e não uma constante antropológica (Gollain, 2000, p. 113), que foi "imposta à força” aos seres humanos (Gollain, 2000, p. 112).

Françoise Gollain propõe, então, que se adote "uma definição historicista [...] do trabalho", capaz de reconhecer que ele "é uma invenção do capitalismo" (Gollain, 2000, p. 11, grifo nosso). A abordagem historicista ao trabalho parte do princípio de que

[...] a análise de um fato tão profundamente social não pode satisfazer-se com enunciados abstratos e intemporais. [...] Procurar subsumir a diversidade histórica sob uma unidade formal é incorrer no risco de um pensamento 'descontextualizado' que sofre de um défice de significado: um pensamento que não explicita em muitos casos a natureza da articulação entre o indivíduo e o social, ou entre o descritivo e o normativo, o presente e o possível (Gollain, 2001, p. 176, grifo nosso). 
Na ótica da autora, para superar uma visão etnocêntrica - que retroprojeta as categorias modernas nas sociedades pré-capitalistas - é necessário "apreciar as descontinuidades da história e da geografia das atividades humanas e propor uma definição restritiva, que entendemos ser mais rigorosa, do conceito de trabalho. (Gollain, 2000, p. 117, grifo do autor).

Em outros termos, as "caraterísticas específicas" do trabalho identificadas pela abordagem historicista - o seu caráter abstrato, homogêneo, mensurável, desvinculado, etc. - "justificam [...] a asserção de que o trabalho é uma invenção da modernidade" (Gollain, 2000, p. 117-118, grifo do autor). Os conceitos das ciências sociais devem possuir um conteúdo preciso e ser "enriquecidos pela diferença" (Gollain, 2000, p. 119), isto é, permitir o entendimento de realidades históricas e sociais completamente distintas, regidas por lógicas incomparáveis. Reconhecer a historicidade do trabalho significa apreendê-lo como "prática social" específica (Gollain, 2001, p. 178, grifo nosso).

\section{SERGE LATOUCHE: o trabalho e o imaginário econômico}

Serge Latouche (2005, p. 7) apreende a historicidade do trabalho no contexto mais abrangente da invenção da economia. Na perspetiva do autor, a emergência da economia pode ser analisada a partir de três pontos de vista "interdependentes e complementares: 1) a invenção teórica da economia; 2) a invenção histórica; e 3) a invenção semântica”.

A invenção teórica refere-se ao surgimento de uma ciência específica: a economia política (Latouche, 2005, p. 8). A invenção histórica diz respeito à criação de um conjunto de práticas sociais - "[...] o trabalho, a produção, o consumo, a poupança, o dinheiro" (Latouche, 2005, p. 8) - que estruturam uma esfera particular desincrustada da sociedade moderna: a economia. Finalmente, a invenção semântica refere-se ao imaginário econômico - ao conjunto de repre- sentações teóricas, ideológicas, simbólicas, do senso comum, etc. - que acompanhou o advento da economia como disciplina e como realidade social (Latouche, 2005, p. 8-9).

Embora Latouche dedique uma atenção especial à invenção semântica (Latouche, 2005, p. 20), no âmbito deste artigo, interessam-nos, sobretudo, suas reflexões acerca da invenção histórica da economia e da atividade econômica par excellence: o trabalho. Falar de uma "invenção da economia" significa problematizar sua própria existência; por outras palavras, a economia não é entendida como uma realidade óbvia, autoevidente, que careceria de explicação (Latouche, 2005, p. 13).

Segundo Latouche, é necessário proceder a uma "desconstrução da economia" (Latouche; Jappe, 2011, p. 4). Nesse contexto, “o recurso à antropologia aparece como um prolegômeno de toda a historicização da economia” (Latouche, 2005, p. 112, grifo do autor). Apoiando-se nos achados empíricos de diversos autores, Latouche empreende uma análise da (re)produção material das sociedades pré-modernas (Latouche, 2005, p. 66-72). Porém sua teorização é bastante semelhante àquela proposta por Dominique Méda, pelo que me limitarei a algumas observações breves.

Latouche reconhece que, nas sociedades pré-capitalistas, existem, obviamente, práticas humanas ligadas à reprodução material da sociedade (Latouche, 2005, p. 14-15). No entanto, é errado afirmar que essas sociedades possuíam uma economia:

Visto que a sobrevivência material da espécie ou a reprodução dos grupos sociais não está autonomizada, nem é pensada como uma esfera à parte, não existe vida econômica, apenas existe a vida tout court. A economia pressupõe a autonomia relativa de um domínio - e a existência, a seu lado, de um domínio 'exterior' à economia -, o que implica determinadas representações, as palavras para dizê-lo, as instituições para fazê-lo (Latouche, 2005, p. 15).

Ao longo da história, nas mais variadas civilizações, as relações comerciais são bastante incipientes e os mercados praticamente 
inexistentes. Apenas no final da Idade Média é que o comércio exterior se vai fundir com os mercados domésticos e, assim, impulsionar "a vida econômica em extensão e intensidade” (Latouche, 2005, p. 15). A generalização da troca mercantil conduz à criação de uma esfera econômica autônoma, isto é, de um sistema de mercado capaz de "funcionar e se autorreproduzir independentemente” (Latouche, 2005, p. 55). A economia é um "processo histórico e cultural” (Latouche, 2005, p. 17), um produto exclusivo da modernidade ocidental (Latouche, 2005, p. 15).

Na ótica do autor, "a instituição do trabalho [...] ilustra um aspecto fundamental da invenção da economia"; o trabalho "foi construído historicamente no discurso e $[\ldots]$ na prática $[\ldots]$ [como, NM] um elemento-chave" da economia capitalista (Latouche, 2005, p. 79). Latouche (2005, p. 12, grifo do autor) atribui o devir histórico do trabalho a fatores de índole ideológica. Trata-se da "emergência e consolidação de um imaginário econômico”, no seio do qual o trabalho adquire uma enorme proeminência.

Em primeiro lugar, o trabalho é entendido por Latouche como uma ideologia propagada pela classe burguesa: "o trabalho é uma invenção da burguesia" (Latouche, 2005, p. ^ 63). Essa ideologia do trabalho almejava asseస्. gurar e justificar a ascensão social dessa classe ป que, para tanto, teve de criticar e deslegitimar o domínio da aristocracia. A "propaganda "tra¿ balhista", difundida entre os séculos XVI e XVIII, foi um instrumento fulcral dessa crítica da nobreza (Latouche, 2005, p. 63). Assim, $\rightarrow$ o trabalho dos burgueses citadinos era apresentado como a fonte do bem-estar e como o i fundamento legítimo de sua riqueza. Os aristocratas, pelo contrário, eram descritos como meros parasitas ociosos que se apropriavam da riqueza alheia (Latouche, 2005, p. 64).

O imaginário promovido pela burguesia é aquele do homo faber e, em particular, do "artesão livre" (Latouche, 2005, p. 64). Esse mundo idílico contrasta com a alienação real ligada ao trabalho assalariado, com a atividade embrutecedora da classe operária nascente, marcada pela "submissão formal e real ao capital” (Latouche, 2005, p. 64). Todavia, se os seres humanos resistiram inicialmente à sua transformação em trabalhadores "livres" - o trabalho teve de ser imposto de modo violento -, os próprios proletários acabariam por aceitar esta "construção ideológica” como um fato natural (Latouche, 2005, p. 64).

Em segundo lugar, Latouche concorda com a tese weberiana acerca do papel da ética protestante no advento da sociedade capitalista. A Reforma e, em particular, a obra de Calvino, instauram "o reconhecimento do trabalho como valor universal” (Latouche, 2005, p. 76). Doravante, “[...]o exercício de uma profissão e o trabalho não serão uma maldição reservada a alguns [...], mas uma verdadeira vocação" (Latouche, 2005, p. 76, grifo do autor) que pode conduzir ao enriquecimento terreno do indivíduo, comprovando, desse modo, seu estatuto de eleito aos olhos de Deus.

De acordo com Latouche, "a ética protestante constitui o momento decisivo para o triunfo da ideologia do trabalho e para a instituição do trabalho no imaginário social" (Latouche, 2005, p. 76). Essa "propaganda trabalhista" não se limitou a transformar as mentalidades dos fiéis protestantes; sua mensagem era "[...] universalista e contribuiu para estabelecer a universalidade do paradigma do trabalho" (Latouche, 2005, p. 76). Em suma, “[...] a individuação do cristão face a Deus converte-se progressivamente na solidão dos cidadãos iguais e indiferenciáveis perante a lei e perante o mercado, incluindo o mercado de trabalho." (Latouche, 2005, p. 75).

Em terceiro lugar, e de modo semelhante às teses aventadas por Dominique Méda, Latouche preconiza que esse individualismo é a pré-condição necessária para

[...] a emergência da economia e, desse modo, do trabalho. O individualismo [...] implica que a $\mathrm{Hu}-$ manidade seja constituída por uma pluralidade de 
átomos idênticos confrontados com uma natureza fundamentalmente hostil. A sobrevivência destas 'partículas elementares' passa por uma atividade de luta contra a natureza e de transformação agressiva da mesma. Este combate penoso e universal virá a ser o trabalho. O indivíduo não é, portanto, a pessoa com as suas raízes, a sua história, os seus laços diversos e os seus projetos, mas o ser anônimo com necessidades de que o homo economicus é o protótipo (Latouche, 2005, p. 74).

Apenas quando o "universo do status" é substituído pelo "universo do contractus" é que "o «trabalho» pode aparecer plenamente" (Latouche, 2005, p. 75) como realidade, com um "caráter universal e abstrato" (Latouche, 2005, p. 74). Por conseguinte, "o termo 'trabalho', em sua acepção atual, é uma invenção recente" (Latouche, 2005, p. 68). A sociedade capitalista é a primeira sociedade do trabalho (Latouche, 2005, p. 74).

\section{ANÁLISE COMPARADA DOS AU- TORES}

Na Figura 1 estão sintetizadas as principais diferenças entre os modos de (re)pro-

Figura 1 - A invenção do trabalho

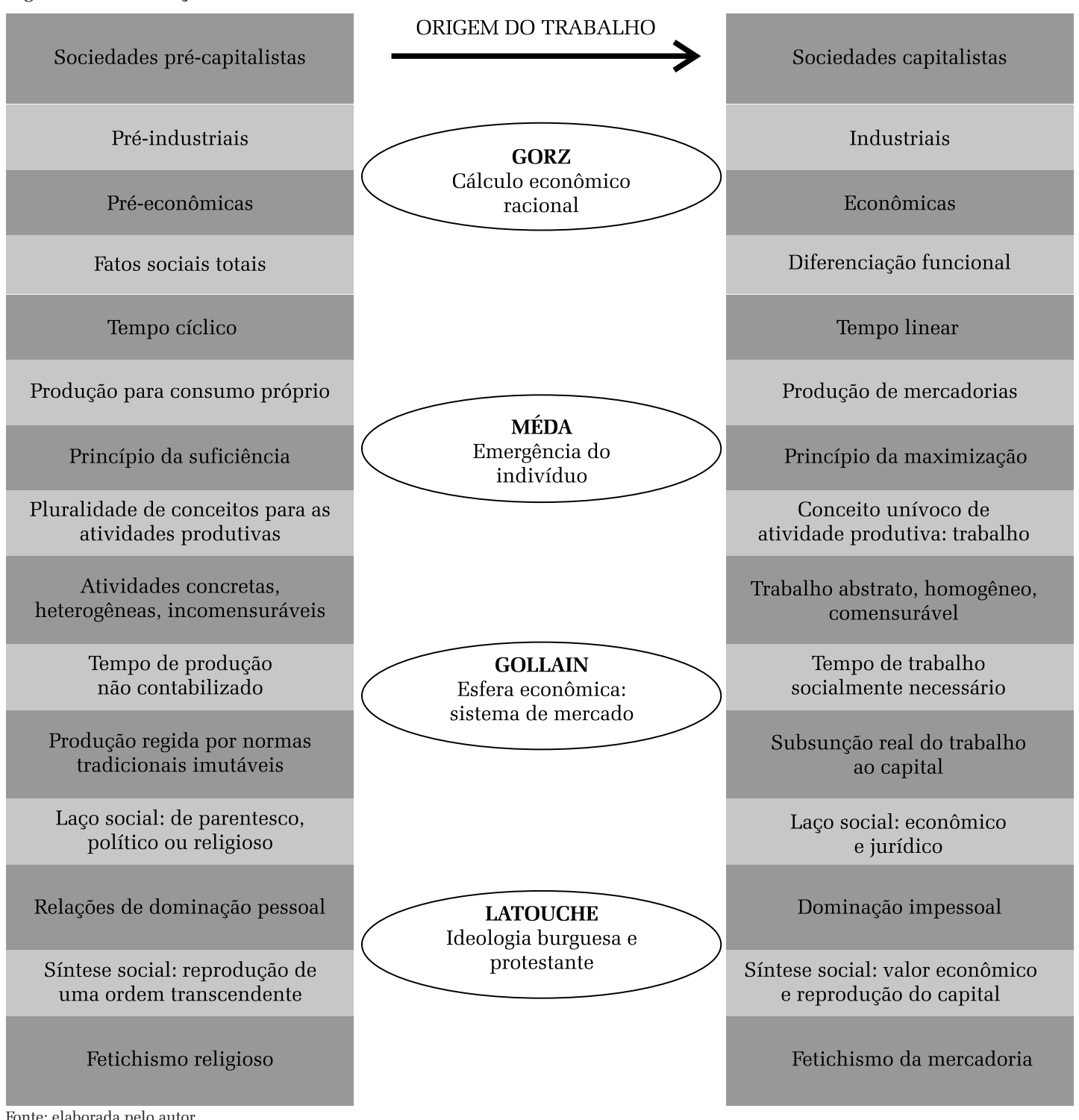


dução das sociedades pré-capitalistas e das sociedades capitalistas. De uma maneira geral, os quatro autores estudados estão de acordo quanto às caraterísticas fundamentais das sociedades pré-modernas. Assim, trata-se, em primeiro lugar, de sociedades pré-industriais, com um nível de desenvolvimento tecnológico relativamente baixo. Para além disso, são formações sociais pré-econômicas, isto é, sua (re)produção material não constitui uma esfera autônoma desvinculável dos outros momentos da vida social: magia, religião, cultura, etc. Relembrando a definição célebre de Marcel Mauss, pode dizer-se que não existem fatos econômicos mas fatos sociais totais.

As sociedades pré-capitalistas são ordenadas por uma noção de tempo cíclico, pontuado pelos ritmos "naturais" ditados pelas estações do ano e pelas inúmeras festividades religiosas, por exemplo. E. P. Thompson (1967, p. 60) fala de um tempo "orientado para as tarefas" concretas realizadas no contexto da família ou da pequena agricultura. A produção para consumo próprio é claramente dominante, tendo por missão responder às necessidades limitadas impostas pelo princípio tradicional da suficiência.

Não existe um conceito unívoco para classificar e subsumir as atividades produtin vas. Esse fato é justificado pela ausência real จे do trabalho como categoria social. As ativida๙ des são vincadamente heterogêneas e regidas por lógicas irredutivelmente diversificadas; elas são incomensuráveis e, por isso, incomparáveis. É completamente estranha a noção de um dispêndio abstrato de energia (o trabalho abstrato) que produz uma objetividade fantasmagórica (o valor econômico). A duração temporal das atividades de (re)produção não é sequer tida em conta, porquanto o seu ritmo obedece a normas tradicionais imutáveis. O progresso técnico é bastante lento e, em alguns casos, quase estacionário.

O laço social está ancorado nas relações de parentesco (sociedades primitivas), nas relações políticas (Grécia e Roma antigas) ou na comunidade de fiéis (sociedade medieval). Os seres humanos estão inseridos em relações de dominação pessoal e de senhoriagem que originam uma série de obrigações recíprocas, cuja finalidade é assegurar a reprodução de uma ordem fetichista transcendente. Os preceitos de índole religiosa regulam a síntese social.

Gorz, Méda, Gollain e Latouche estão igualmente em sintonia quanto às principais características das sociedades capitalistas (conferir Figura 1). Elas são sociedades industriais com um nível elevadíssimo de desenvolvimento tecnológico e científico. Ademais, as sociedades modernas são sociedades econômicas, ou seja, a (re)produção material da sociedade - que é igualmente uma reprodução das relações sociais de valor - constitui uma esfera desincrustada, um sistema de mercado. No contexto da diferenciação funcional hodierna, a esfera econômica possui um claro ascendente sobre as demais esferas de atividade, em virtude da mercadorização das relações sociais.

Nas sociedades capitalistas vigora uma noção de tempo linear e abstrato (Thompson, 1967, p. 57). Tal entendimento do tempo - consubstanciado na sua medição rigorosa ao milésimo de segundo - é indissociável da racionalização, cientificização e sincronização das atividades de produção, assim como da disciplina fabril e da relação estreita entre (tempo de) trabalho e dinheiro. As sociedades modernas são sistemas produtores de mercadorias. Os bens são produzidos com vistas à sua venda no mercado e à obtenção de lucro. O princípio da maximização da produção, da produtividade e do lucro norteia a vida social no seu conjunto.

A miríade das atividades produtivas está subsumida no conceito unívoco de trabalho. Esse conceito traduz a uniformidade real do trabalho como categoria econômica. O trabalho que produz valor econômico é abstrato, homogêneo, instrumental, mensurável e assalariado. A força de trabalho - a capacidade abstrata de dispêndio de energia física e mental - é desvinculável do seu portador e transacionável. 
O capitalismo assenta no revolucionamento contínuo das forças de produção, no progresso técnico incessante. A concorrência entre os vários capitais difunde um padrão $o b$ jetivo de produtividade que deve forçosamente ser cumprido: o tempo de trabalho socialmente necessário; a intensidade do trabalho é, pois, elevada. A subsunção real do trabalho ao capital resulta na criação de um modo de (re) produção material historicamente específico, adequado ao fim em si mesmo irracional da valorização do valor.

O laço social burguês está ancorado em leis econômicas objetivas e em normas jurídicas abstratas: o indivíduo moderno é um trabalhador e um sujeito de direito. Para assegurar sua sobrevivência, ele tem de provar que sua força de trabalho é útil para a combustão capitalista. Os seres humanos estão, portanto, inseridos em relações de dominação impessoais: seu destino está entregue ao fetichismo da mercadoria, isto é, ao funcionamento quasi-objetivo de abstrações reais (valor, dinheiro, trabalho, mercado, capital). O trabalho abstrato e a troca mercantil são as categorias basilares responsáveis pela síntese social capitalista, cuja finalidade é a reprodução alargada do capital.

Finalmente, como se depreende na Figura 1, os quatro autores divergem quanto à razão explicativa aventada para a gênese histórica do trabalho. André Gorz defende que foi a necessidade de calcular os custos da matéria-prima e do trabalho, ou seja, o cálculo econômico racional promovido pelos mercadores que, ao conquistar e transformar o modo de produção, esteve na origem do trabalho e de uma sociedade regida pela racionalidade econômica.

Obviamente que o cálculo instrumental acompanhou o devir do trabalho, mas Gorz ignora que, se os produtos não começassem a assumir previamente a forma generalizada de mercadorias, então não seria preciso calcular quaisquer "custos", porque a forma-valor não nortearia a reprodução social. O camponês medieval, por exemplo, não fazia nenhum cálculo econômico porque não vendia seus produtos
- eles não adotavam a forma de mercadorias. É a hegemonização da forma-mercadoria, a sua conquista progressiva da reprodução material e social da humanidade, que impõe o domínio quasi-objetivo do valor e do trabalho abstrato, engendrados por detrás das costas dos indivíduos. Não foi o cálculo subjetivo que criou o valor, o trabalho e as relações mercantis; pelo contrário, foram as relações mercantis que disseminaram o cálculo econômico e a racionalidade instrumental.

Dominique Méda identifica o advento concomitante do indivíduo e do trabalho. Todavia a autora vai mais longe do que isso e defende que o trabalho foi a resposta à emergência histórica do indivíduo na esfera pública. Por vezes, Méda parece mesmo sugerir que o trabalho foi uma espécie de artifício inventado para integrar socialmente o indivíduo. Essa abordagem parece-me ser equivocada, pois não creio que se possa atribuir o nascimento do indivíduo a uma estratégia consciente, nem que seja possível afirmar categoricamente que o indivíduo precede historicamente o trabalhador. É um daqueles casos em que se torna difícil dizer o que surgiu primeiro: o ovo ou a galinha.

Por um lado, as enclosures e a expulsão dos camponeses das suas terras criaram uma classe de trabalhadores formalmente livres, que são obrigados a vender sua força de trabalho. Por outro lado, é impossível não vislumbrar, na figura do trabalhador - do proprietário de si -, o embrião do sujeito de direito moderno: o cidadão. Em suma, creio ser mais rigoroso entender o sujeito como uma figura esquizoide desde sua origem, cindida entre o bourgeois da sociedade civil e o citoyen da esfera político-jurídica, recorrendo aos termos propostos por Marx (1993).

Quanto a Françoise Gollain, sua explicação para a "invenção do trabalho" é quase tautológica. A autora nos diz que o trabalho surge na sequência da Revolução Industrial e da constituição de um sistema de mercado autorregulado; o trabalho deve ser apreendido no contexto da formação de uma sociedade eco- 
nômica. Essa tese não oferece grande contestação. Porém Gollain revela-se incapaz de esclarecer o porquê de esse sistema de mercado ter surgido na Europa, numa época histórica específica. $^{19}$

Serge Latouche explica o advento do trabalho em termos weberianos: a ideologia da classe burguesa e a ética protestante constituem o "espírito do capitalismo" que fermentou o trabalho. Nesse sentido, o trabalho aparece como o resultado de um processo discursivo que instituiu um novo "imaginário", de natureza econômica. Por outras palavras, a transformação real das atividades produtivas e a criação do trabalho como categoria eminentemente social são relegadas para segundo plano na sua análise. A essa visão deve se contrapor que "o discurso econômico acompanhou uma transformação da prática [social, NM] real" (Latouche; Jappe, 2011, p. 13), ou seja, as reflexões dos teólogos, a teoria da economia política e o senso comum da burguesia devem ser entendidos como discursos ideológicos legitimadores de uma nova realidade social: a economia.

Pode-se concluir que os quatro autores identificam corretamente um fator particular diretamente ligado à emergência histórica do trabalho. Todavia nenhum desses fatores, n tomado isoladamente, é capaz de explicar : satisfatoriamente o nascimento da socieda๙ de do trabalho. Anselm Jappe relembra que, (Parker, 2013), no século XVI, que inaugurou a ${ }^{19}$ Essa questão será abordada um pouco mais à frente. era moderna no mundo ocidental. Segundo Jappe, será legítimo afirmar que foi "[...] a revolução das armas de fogo que permitiu superar um certo limiar qualitativo no que se refere à emergência da economia, da sociedade capitalista na Europa."(Latouche; Jappe, 2011, p. 15).

A guerra converte-se num empreendimento bastante dispendioso. Os canhões e as fortalezas já não podiam ser construídos de modo artesanal, pelo que foram impulsionadas as primeiras manufaturas (Latouche; Jappe, 2011, p. 16). Anselm Jappe explica que os príncipes precisavam obter dinheiro para remunerar

[...] os engenheiros e os operários que fabricavam as armas de fogo e construíam as novas fortalezas. Os soberanos tinham, doravante, necessidade de somas avultadas de dinheiro, sendo nesta época que os Estados começam a cobrar impostos cada vez mais elevados sob a forma monetária igualmente para pagar aos novos especialistas desta guerra fora das relações de vassalagem: os soldados, que, segundo a etimologia, são aqueles indivíduos que recebem um soldo para fazer a guerra. O soldado é o primeiro assalariado do mundo moderno, que não deve ser pago em espécie, mas em dinheiro. Soldado que abandona o seu trabalho se não for pago. Encontramos [...] no mercenário e [...] no condottiere que organiza os soldados o modelo do trabalho assalariado capitalista [...]. Para financiar esta nova forma de guerra, os Estados começam, portanto, a cobrar os impostos principalmente sob a forma monetária, pressionando os camponeses e os artesãos no sentido de se tornarem trabalhadores para poderem pagar impostos cada vez mais elevados.(Latouche; Jappe, 2011, p. 16).

A gênese da economia e do trabalho deve, pois, ser procurada na revolução militar que deu início a um processo bipartido de monetarização das relações sociais:

1. cobrança de impostos em dinheiro para financiar a nova forma de fazer a guerra; $\mathrm{e}$

2. pressão para que os seres humanos exercessem atividades assalariadas, de modo a conseguirem pagar esses mesmos impostos.

Em súmula, "o capitalismo ocidental nasce $[\ldots]$ com a força destrutiva das armas de fogo $[\ldots]$, porque elas põem em movimen- 
to uma dinâmica que não tinha sido desejada [...] por nenhuma pessoa, uma dinâmica que se estabelece por trás das costas dos indivíduos” (Latouche; Jappe, 2011, p. 15-16)

\section{CONCLUSÃO: da historicidade do trabalho às relações sociais de fetiche}

Neste artigo, demonstrou-se que André Gorz foi pioneiro na proposta da abordagem historicista ao trabalho no mundo francófono, apreendendo-o como uma categoria exclusiva da civilização moderna, uma forma de atividade realizada numa esfera econômica autônoma. Trata-se de uma substância homogênea, abstrata e mensurável que, ao produzir valor econômico, está no cerne da síntese social capitalista.

Outros autores seguiram as pisadas de Gorz. Foram apresentadas as teorias de três desses autores: Dominique Méda, Françoise Gollain e Serge Latouche. Na sequência de uma análise comparada, destacaram-se: i) o entendimento semelhante do modo de funcionamento das sociedades pré-capitalistas, assim como das caraterísticas basilares da reprodução social capitalista; ii) a divergência quanto aos fatores explicativos do surgimento histórico do trabalho. Foi sugerido que esses fatores explicativos podem ser enquadrados no contexto comum, providenciado pela chamada "revolução militar" (Parker, 2013), que assinala o início da modernidade europeia.

A noção de trabalho como categoria ontológica, trans-histórica, encontra-se disseminada no campo das ciências sociais. Essa ontologia está intimamente associada a uma definição materializante do trabalho. Assim, quero concluir este artigo com duas notas adicionais. Em primeiro lugar, recuperando o conceito marxiano de subsunção real, cabe ressalvar que, na modernidade, é criado um modo de (re)produção material especificamente capitalista, pelo que a noção de produção "em geral", materialmente idêntica em todas as formações sociais, carece de sentido (Machado, 2017). A economia é um processo de produção de valor econômico e um processo de reprodução material da sociedade capitalista moldado por esse processo de valorização.

Em segundo lugar, de acordo com a definição materializante trans-histórica, o trabalho e a economia "existiriam [...] independentemente de qualquer relação social” (Freyssenet, 1999, p. 1); seriam, portanto, paradoxalmente realidades pré ou associais. Ora, deve ser salientado que "[...] a produção material é ela mesma um produto totalmente social e histórico, tal como [...] as outras manifestações humanas" (Freyssenet, 1999, p. 6). Nesse sentido, o prius nunca é a (re)produção material em si mesma ${ }^{20}$, mas a reprodução social que, até hoje, foi sempre a reprodução de certas relações sociais de fetiche.

A história da Humanidade pode, portanto, ser lida como uma história das relações de fetiche (Kurz, 2014, p. 63-78). A reprodução material e a correspondente satisfação das necessidades individuais e sociais estão subordinadas à constituição-fetiche prevalecente numa dada sociedade. Segundo Clément Homs, “[...] a constituição-fetiche [...] é um processo social mediante o qual os homens criam uma estrutura de inter-relações que depois os domina" (Homs, 2012, p. 151). Por outras palavras, "[...] os indivíduos vivem como criadores de relações sociais reificadas que possuem aparentemente a sua 'vida própria', relações de que os indivíduos são ao mesmo tempo criadores e criaturas" (Homs, 2012, p. 193). Isso significa que a reprodução social é a base sobre a qual repousa a reprodução material. A reprodução material apenas é cumprida na medida em que possibilita a reprodução das relações sociais de fetiche.

Nesse sentido, é o princípio fetichista estruturante que determina o conteúdo das necessidades e a forma de sua satisfação. Não existe tal coisa como o indivíduo associal,

${ }^{20}$ Tal como defende o "materialismo histórico" postulado pelo marxismo tradicional, por exemplo. 
isolado, robinsoniano, que procura satisfazer suas necessidades através de um intercâmbio material com a natureza invariável, imutável e trans-histórico. Existem indivíduos inseridos em sociedades específicas, que obedecem a um determinado tipo de organização social e que definem aquelas que são consideradas as necessidades individuais nesse contexto histórico particular. A subsistência material dos indivíduos sociais está sempre subordinada à reprodução macrossocial regida por certo modo de organização fetichista.

Por exemplo, em várias sociedades pré-capitalistas, "antes de poder comer é preciso oferecer a parte consagrada ao deus, antes de se abrigar é preciso construir o templo, etc." (Homs, 2012, p. 175). De maneira análoga, hoje em dia, a "satisfação das necessidades" é um efeito secundário da síntese social capitalista. A necessidade primordial da sociedade burguesa é a valorização do valor. As necessidades individuais e sociais apenas são satisfeitas na medida em que possibilitarem a reprodução alargada do capital. O indivíduo apenas garante o direito à subsistência e, num nível ainda mais elementar, à sobrevivência física, se provar ser útil para esse processo incessante de valorização, ou seja, se o consumo produtivo de sua força de trabalho for economicamente rentável.

O crescente número de indivíduos supérfluos, que morrem simplesmente de fome ou de frio, demonstra que, inclusive nas sociedades modernas, na qualidade de sociedades fetichistas, a reprodução material da sociedade não é o fator determinante apriorístico da reprodução social. Pelo contrário, essa reprodução material apenas é garantida se possibilitar a reprodução social de caráter historicamente específico: a reprodução das relações sociais de valor.

Visto que as diferentes civilizações humanas, ao longo da história, são baseadas em relações de fetiche particulares, é impossível construir uma teoria social geral e universalmente aplicável. Aquilo que se exige às ciências sociais e humanas é, ao invés, que construam uma "teoria social-histórica específica"
(Homs, 2012, p. 149, itálico nosso) para cada tipo de sociedade e, por conseguinte, para cada tipo de constituição-fetiche que a estrutura. Nesse contexto, a teorização da sociedade capitalista terá de ser capaz de dar conta de sua excecionalidade histórica como primeira sociedade econômica estruturada pelo fetichismo do valor e da mercadoria.

Recebido para publicação em 05 de junho de 2017 Aceito em 25 de julho de 2017

\section{REFERÊNCIAS}

ARENDT, H. The Human Condition. Chicago: The University of Chicago Press, 1998.

BISCHOFF, M. L'humanité a-t-elle toujours "travaillé"?Théologiques, [Montréal], v. 3, n. 2, p. 45-69, 1995.

BOTELHO, M. Crise da sociedade do trabalho: teorias em conflito. 2009. $380 \mathrm{f}$. Tese (Doutorado em Desenvolvimento, Agricultura e Sociedade) - Instituto de Ciências Humanas e Sociais, Universidade Federal Rural do Rio de Janeiro, Rio de Janeiro, 2009.

CASTEL, R. André Gorz et le travail: une interprétation critique. In: CASTEL, R.; FOUREL, C. (Ed.). Sortir du capitalisme: le scénario Gorz. Paris: Le Bord de L'eau, 2013. p. 43-56.

CHAMOUX, M. Sociétés avec et sans concept de travail. Sociologie du Travail, Paris, v. 36, p. 57-71, 2001.

FREYSSENET, M. Invention, centralité et fin du travail. [Paris], 1999. Disponível em: <http://freyssenet.com/ files/Invention, \%20centralite\%CC\%81\%20et\%20fin\%20 du\%20travail.pdf $\geq$. Acesso em: 8 fev. 2017.

GOLLAIN, F. Une critique du travail: entre écologie et socialisme. Paris: Éditions La Découverte, 2000.

GOLLAIN, F. Penser le travail dans sons historicité: Quelques réponses à Yolande Benarrosh. Revue du MAUSS, Paris, n. 18, n. 2, p. 176-195, 2001.

GOLLAIN, F. André, mon maître: Hommage à André Gorz. Revue du MAUSS, Paris, n. 31, p. 545-557, 2008.

GORZ, A. Capitalism, Socialism, Ecology. Londres: Verso, 1994

GORZ, A. Crítica do capitalismo quotidiano (I). Lisboa: Iniciativas Editoriais, 1976a.

GORZ, A. Crítica do capitalismo quotidiano (II). Lisboa: Iniciativas Editoriais, 1976b.

GORZ, A. Critique of Economic Reason. Londres: Verso, 1989a.

GORZ, A. O Despotismo de Fábrica e o seu Futuro. In: GORZ, A. et al. Divisão social do trabalho e modo de produção capitalista. Porto: Escorpião. 1976c. p. 87-97.

GORZ, A. Ecology as Politics. Montréal: Black Rose Books, 1980.

GORZ, A. Ecologie et Socialisme. Ecologie et Politique, Paris, n. 24, p. 71-95, 2002.

GORZ, A. Estratégia Operária e Neocapitalismo. In: GORZ, A. Reforma e revolução. Lisboa: Edições 70. 1975a. p. 73-261. 
GORZ, A. et al. Divisão social do trabalho e modo de produção capitalista. Porto: Escorpião, 1976.

GORZ, A. Fondements pour une morale. Paris: Editions Galilée, 1977.

GORZ, A. Farewell to the Working Class: An essay on PostIndustrial Socialism. Londres e Sydney: Pluto Press, 1982.

GORZ, A. Historia y Enajenación. México: Fondo de Cultura Económica, 1969.

GORZ, A. Paths to Paradise: On the Liberation from Work. Londres e Sydney: Pluto Press, 1985.

GORZ, A. Prefácio. In: GORZ, A. Reforma e revolução. Lisboa: Edições 70. 1975b. p. 7-72.

GORZ, A. Prefácio. In: GORZ, A. et al. Divisão social do trabalho e modo de produção capitalista. Porto: Escorpião. 1976d. p. 7-18.

GORZ, A. Reforma e revolução. In: GORZ, A. Reforma e revolução. Lisboa: Edições 70. 1975c. p. 263-322.

GORZ, A. O socialismo difícil. Rio de Janeiro: Zahar Editores, 1968.

GORZ, A. Técnica, Técnicos e Luta de Classes. In: GORZ, A. et al. Divisão Social do Trabalho e Modo de Produção Capitalista. Porto: Escorpião. 1976e. p. 239-284.

GORZ, A. The Traitor. Londres e Nova Iorque: Verso, $1989 b$.

GRANTER, E. Critical Social Theory and the End of Work. Farnham e Burlington: Ashgate, 2009

HOMS, C.A la recherche du reflet (à jamais) perdu de l'économie dans les sociétés précapitalistes - Pour une critique de l'anthropologie économique. $1^{\text {ère }}$ partie: Critique du substantivisme économique de Karl Polanyi. Sortir de l'économie, [S.l.], n. 4, p. 140-194, 2012.

JAPPE, A. As Aventuras da mercadoria: para uma nova crítica do valor. Lisboa: Antígona, 2006.

KURZ, R. A origem destrutiva do capitalismo. In: KURZ, R. Os últimos combates. Petrópolis: Vozes. 1998. p. 239245.

KURZ, R. Dinheiro sem valor: linhas gerais para uma transformação da crítica da economia política. Lisboa: Antígona, 2014.

LATOUCHE, S. L'invention de l'économie. Paris: Albin Michel, 2005.
LATOUCHE, S.; JAPPE, A. Sortir de l'économie? (ou plutôt comment l'économie a été inventée) - Un débat avec Serge Latouche et Anselm Jappe. 2011. Disponível em: http:// sd-1.archive-host.com/membres/up/4519779941507678/ Sortir de leconomie Retranscription de rencontre avec_Serge_LLatouche_et_Anselm_Jappe_Bourges_2011. pdf $\geq$. Acesso em: 8 fev. 2017.

MACHADO, N. A aporia do conceito de trabalho em Marx: uma análise cronológica. 2017. Disponível em: $<$ http://www.academia.edu/24166630/A aporia do conceito de trabalho em_Marx_uma_an\%C3\%A1Tise-

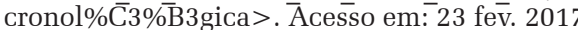

MACHADO, N. De Marx a Illich: economia, ecologia e tecnologia na obra de André Gorz da década de 1970. Análise Social, Lisboa, v. 51, n. 2 (219), p. 240-273, 2016a.

MACHADO, N. A obra gorziana da década de 2000 e a sua relação com a Nova Crítica do Valor. Revista Pós Ciências Sociais, São Luís, v. 13, n. 25, p. 277-304. 2016b.

MACHADO, N. Três vivas ao proletariado! - Para uma contextualizacão da obra gorziana da década de 1960 Revista Brasileira de Ciências Sociais, São Paulo, v. 31, n. 91. 2016c.

MARX, K. Capítulo Inédito d' O Capital: resultados do processo de produção Imediato. Porto: Publicações Escorpião, 1975.

MARX, K. Economic Manuscript of 1861-63. In: MARX, K; ENGELS, F. Collected Works. Londres: Lawrence \& Wishart: 1988. v. 30

MARX, K. A Questão Judaica. In: MARX, K. Manuscritos económico-filosóficos. Lisboa: Edições 70, 1993. p. 33-73.

MÉDA, D. Qué sabemos sobre el trabajo? Revista de Trabajo, [S.l.], ano 3, n. 4, p. 17-32, 2007.

MÉDA, D. Le travail: une valeur en voie de disparation? 2 ème. Paris: Flammarion, 2010.

PARKER, G. The Military Revolution: Military Innovation and the Rise of the West, 1500-1800. Cambridge: Cambridge University Press, 2013.

POSTONE, M. Time, Labor, and Social Domination: A Reinterpretation of Marx's Critical Theory. $2^{\text {nd }}$. Cambridge: Cambridge University Press, 2003.

SILVA, J. André Gorz:trabalho e política. São Paulo: Annablume, 2002.

THOMPSON, E. Time, Work-Discipline, and Industrial Capitalism. Past and Present, [S.1.], n. 38, p. 56-97, 1967. 


\section{THE "INVENTION OF WORK": historicity of a concept in the works of André Gorz, Dominique Méda, Françoise Gollain and Serge Latouche}

\author{
Nuno Miguel Cardoso Machado
}

After the publishing of Farewell to the Working Class, in 1980, the understanding of labor as a historically specific activity peculiar to capitalist modernity is one of the major tenets of the theoretical edifice built by André Gorz. Labor is closely related to the emergence of an economic realm disembedded from society and, as abstract labor, to the irrational end in itself of the valorization of value. In this article, we aim to characterize in detail the evolution of the concept of labor in Gorz's main works and, then, to compare the gorzian notion of the historicity of labor with the ideas of three francophone authors: Dominique Méda, Françoise Gollain and Serge Latouche. We will assess the similarities and the divergences that exist among the mentioned authors. Finally it will be emphasized that the reasons suggested for the historical emergence of labor can be better grasped in the common embryonic context provided by the "military revolution", in the $16^{\text {th }}$ century, which marks the beginning of the modern age in the western world.

KEYwORDS: Labor. Gorz. Méda. Gollain. Latouche.

\section{“L'INVENTION DU TRAVAIL": historicité d'un concept dans les œeuvres d'André Gorz, de Dominique Méda, de Françoise Gollain, de Serge Latouche}

Nuno Miguel Cardoso Machado

Après la publication de Adieux au Proletariat, en 1980, la compréhension du travail, considéré historiquement comme une activité spécifique de la modernité capitaliste, est l'un des piliers de l'édification théorique construite par André Gorz. Le travail est intimement lié à l'apparition d'une sphère économique n’ayant pas de rapport avec la société, et en tant que travail abstrait en soi finalement irrationnel, ni avec la valorisation de la valeur. Dans cet article, nous voulons caractériser en détail l'évolution du concept de travail dans les œuvres principales de Gorz. Ensuite nous comparons cette notion sur l'historicité du travail avec les idées de trois auteurs francophones, à savoir Dominique Méda, Françoise Gollain et Serge Latouche. Nous faisons un relevé analytique des ressemblances et des différences entre les auteurs mentionnés. Enfin, nous pouvons faire remarquer qu'il est plus facile de comprendre les raisons énoncées pour le développement historique du travail dans le contexte embryonnaire commun de la "révolution militaire" du 16ème siècle qui a inauguré l'ère moderne dans le monde occidental.

Mots-cLÉs: Travail. Gorz. Méda. Gollain. Latouche. Doutorado no SOCIUS. 